

Ny/zontributions from the heye museum NMAIREF

NUMBER 9

no. 9

\section{POTTERY FROM CERTAIN CAVES IN EASTERN SANTO DOMINGO, WEST INDIES}

BY THEODOOR DE BOOY

Reprinted from the American ANThropologist (N.S.), Vol. XVII, No. I, January-March, I9I 5

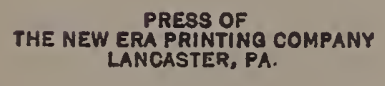

I9I 5

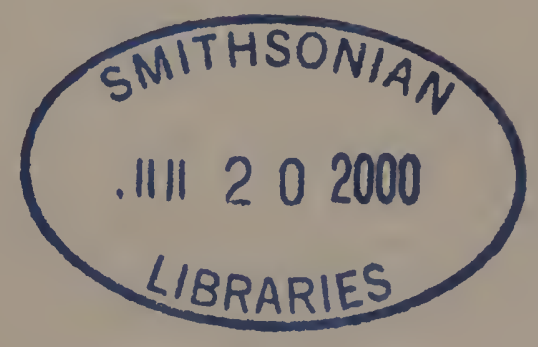





\section{POTTERY FROM CERTAIN CAVES IN EASTERN SANTO DOMINGO, WEST INDIES}

\section{By THEODOOR DE BOOY}

$\mathrm{I}^{\mathrm{T}}$

was the privilege of the author to conduct certain archeological investigations in the Republic of Santo Domingo during the months of July to October, I9r3, in behalf of the Heye Museum of New York City. This expedition confined itself mainly to the eastern part of the Republic, with headquarters first on Saona island and later in the woods near Cape Macao, in the vicinity of a small settlement called Salado (fig. I2).

Both Saona island and the district of Macao are virtually a virgin field to the archeologist. In the numerous general accounts and the comparatively few archeological writings on the island of Santo Domingo the author was able to find only a single mention bearing on the antiquities of the region. This is in a paper by Sir Robert Schomburgk, who makes brief reference to the shell-heaps of Cape Engaño, a promontory south of Cape Macao, ${ }^{1}$ but does not state whether he made further investigation.

\section{EARLy History}

While information respecting the archeology of these regions is meager, one can find in early historical writings a certain amount of data on Saona island, the district of Macao, and in general on the eastern portion of Santo Domingo.

After Columbus had coasted the southern side of Jamaica on his second voyage, he steered eastward and soon saw the coast of Haiti rising above the horizon. He did not know which island this was, as he was familiar only with its northern coast, but on skirting the southern coast he found that he had returned to Hispaniola, when an Indian came off in a canoe to his ship, hailed him by name, and spoke to him in Castilian. ${ }^{2}$ The Admiral continued eastward

1 Schomburgk, Ethnological Researches in St. Domingo, Report of British Associalion for I85I, pp. 90-9I.

2 Irving, Life of Columbus, book vir, chap. vii. 
along the coast, and, passing the islands of Beata and Alto Velo, finally reached Saona and anchored in the channel between that isle and the mainland. Saona was called Adamano, or Adamaney, by the natives. ${ }^{1}$ No mention is made by historians whether or not Saona was found to have inhabitants when Columbus was lying in the channel between it and the mainland, and the author can find no mention of the origin of its present name, Herrera merely men-

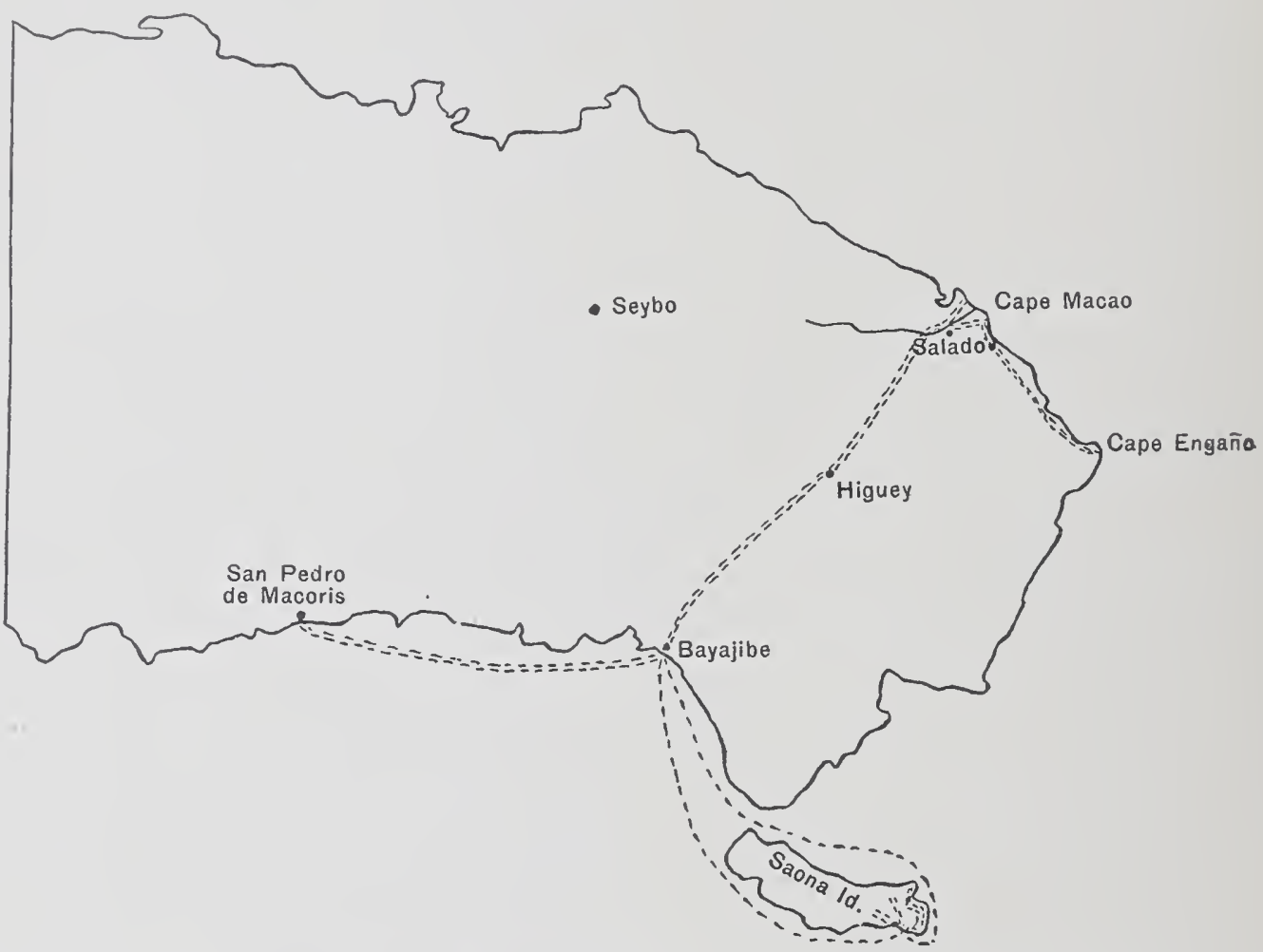

FIG. I2.-Map of eastern Santo Domingo, showing the route traversed.

tioning that the Castilians thus called ${ }^{2}$ it, while Las Casas thought the name Saona was applied to it by the Admiral or the Adelantado, but does not give the reason. ${ }^{3}$ In Irving's Life and Voyages of Christopher Columbus, ${ }^{4}$ we find the following statement: "He [Signor Belloro] states that a public square in that city bore the name of Platea Columbi, towards the end of the I4th century: that

1 Herrera, Historia General de las Indias, dec. I, lib. II, cap. xv. Las Casas, Hist. Ind., lib. I, cap. xcviii.

${ }^{2}$ Herrera, op. cit.

${ }^{3}$ Las Casas, op. cit.

"Appendix, note vi, "The Birthplace of Columbus." 
the Ligurian government gave the name of Jurisdizione di Colombu to that district of the republic, under the persuasion that the great navigator was a native of Savona, and that Columbus gave the name of Saona to a little island adjacent to Hispaniola, among his earliest discoveries." This, then, may be the origin of the name of the island, for while Irving says that the proofs which Signor Belloro brings forward to show that the Admiral was born in Savona are fallacious, he does state that the records show that the father of Columbus was for a long time resident of the town named. It may therefore well be that Columbus named the island in memory of his father.

We next find in the ancient chronicles that Saona was frequently visited after the establishment of the city of Santo Domingo on the southern coast of Haiti, and that the inhabitants of this settlement held constant communication with the natives of the island in order to obtain cassava bread. These relations appear to have been friendly for some time, and the aborigines of Saona readily: supplied their visitors with provisions. ${ }^{1}$ Owing to the customary Spanish cruelty, however, this condition of affairs did not last long. On one occasion a party of Spaniards came to Saona in a shallop and were well received as usual. It so happened, however, that one of the bloodhounds which accompanied the soldiers saw the cacique. of the island moving about with a staff in his hand, directing the activities of his followers who were loading the Spanish vessel: The dog, under the impression that the cacique was making threatening motions, strained at his leash, and the Spaniard holding the animal, thinking to have some sport, released the hound, which forthwith sprang at the chieftain and killed him. The enraged followers fell upon the Spaniards and killed eight of them before the remainder could escape to their boat. ${ }^{2}$

This occurrence being reported in the city of Santo Domingo, orders were given to Don Juan de Esquibel (who at the time was about to undertake an expedition of conquest against the inhabitants of the Higuey district, to whose chief cacique, Cotubanama, the cacique of Saona owed allegiance) to make a special

${ }^{1}$ Las Casas, op. cit., lib. Ir, cap. vii.

${ }^{2}$ Ibid. 
trip to Saona in order to avenge the death of the eight Spaniards. Esquibel had with him a party of about $35^{\circ} \mathrm{men}$, some of whom were sent to Saona. ${ }^{1}$

The scenes following the landing of this expedition baffle description. The Indians, on discovering the hostile intentions of the invaders, gave battle, but to no avail: their arms were of small use against the cuirasses of the Spaniards, and their stone weapons no match for the swords and spears of their enemies. After great slaughter the surviving Indians retreated to the hills and caverns, but even here they were pursued, and Las Casas mentions that about 600 or 700 of them were found in one place and put to the sword. We must here make allowance for the historian, as it is not likely that so many Indians lived on Saona island or that they were found in one "casa" (house), as related by Las Casas, who received his information from hearsay and probably was misinformed respecting the number of Indians mentioned. Nevertheless, after this expedition no aborigines remained on Saona; such as were not killed were taken as slaves and the island depopulated. ${ }^{2}$

The early writers make one more mention of Saona island. After the second war on the inhabitants of Higuey, Cotubanama, the cacique of that district, fled to Saona with his wife and children and a few followers, who hid themselves in some caves in the interior. ${ }^{3}$ Another expedition was sent to capture Cotubanama, and he was finally made prisoner and taken to Santo Domingo City, where he was hanged by order of Ovando. ${ }^{4}$

From all accounts Saona appears not to have been inhabited after the massacre of its native inhabitants about $\mathrm{I}_{502}$. The author has been able to find only one account to the contrary; this is in a modern work by Samuel Hazard, but no original authority can be found in support of his statement. $\quad$ This author says: "The course of the steamer being now entirely changed, she heads almost due west, and we pass the island of Saona, once famous in the annals

${ }^{1}$ Las Casas, Hist. Ind., lib. II, cap. viii.

${ }^{2}$ Ibid.

3 Ibid., cap. xvii.

${ }^{4}$ Ibid., cap. xviii.

${ }^{5}$ Samuel Hazard, Santo Domingo, Past and Present: with a glance at Hayti, New York, 1873 , p. 207. 
of the Jesuits as a place where they held exclusive control over fertile fields. It is as large as the Dutch island of Curacoa and said to be infinitely more fertile, though now desolate and unproductive." It cannot be urged that $\mathrm{Mr}$ Hazard may have meant that the period of "exclusive control over fertile fields" antedated the massacre of the Indians, as the Jesuit order was not established in Europe until I 534, whereas the massacre of Saona took place about I5O2; and even if the Jesuits had settled on the island in later years, some traces of their occupancy, such as the walls of houses or the walls surrounding fields, would be visible. While the present writer did not visit the western portion of the island, he saw no evidence of such occupancy in the eastern half. Several fishermen from the village of Bayajibe, on the adjacent mainland, assured him that they had often walked through the interior of western Saona and along its shores, but had never seen any remains of buildings.

The history of the district of Macao and Higuey is essentially the same as that of the island of Saona, so far as the aboriginal inhabitants are concerned. Bloodshed, rapine, and wanton destruction of agricultural property, the main resource of a non-mineral country like the district of Macao, mark the brief period of existence of the Indians after the Spanish invasion. When the Spaniards established their rule on Haiti, the eastern portion of the island was known by the Indian name of Higuey and was ruled by the powerful cacique Cotubanama. The inhabitants of this province were the most warlike of the island, having become proficient in the use of defensive weapons probably through the frequent invasions of the Caribs from the neighboring islands to the eastward. The cacique himself has been described by Las Casas, who refers to him as the strongest and tallest man of his tribe; that his bow was so strong that a common man could not bend it, and that his other weapons resembled those of a giant. ${ }^{1}$

About the time of the killing of the eight Spaniards by the inhabitants of Saona, the Indians of Higuey province, under the leadership of Cotubanama, revolted against Spanish rule. Their relations with the invaders had already become strained, owing

\footnotetext{
${ }^{1}$ Las Casas, Hist. Ind., libro Ir, cap. xvi.
} 
to the demands made upon them; and for some time they had been aware that their first conception that the Spaniards were supernaıural beings was a delusion. A Spanish officer, Juan de Esquibel, was dispatched by Ovando from Santo Domingo City in 1504 to punish the natives, and after a few insignificant defeats Esquibel succeeded in driving the Indians to the mountains; but the luckless people were doggedly pursued and systematically killed whenever discovered. ${ }^{1}$ Finally, in desperation, the natives sued for peace, which was granted them on harsh terms: they were to cultivate land for the invaders and pay tribute in provisions. Esquibel built a wooden fort in an Indian village near the sea, probably where now is the pueblo of Higuey, and left in it a guard of nine men under Captain Martin de Villaman, who was supposed to collect the tribute and to enforce the cultivation of the land.

This peace was of short duration. The resident Spaniards of Higuey, following the usual practice, treated the Indians with great cruelty, made demands on them to which they could not accede, while women were taken from their husbands and fathers, and abused. Driven to desperation the Indians rose against the Spaniards, set fire to the fort, and killed the defenders. ${ }^{2}$ This revolt forced the Spanish governor to organize another expedition against the natives, again under the command of Esquibel.

Las Casas, then a young man of twenty-eight, was a witness of the greater part of this second campaign, and while it was not until twenty-five years later that he commenced to write his history of the West Indies, a work which was not finished until he was eightyfive years of age, the cruelties of this campaign made such a vivid impression on him that oftentimes he thought the scenes he witnessed were the result of an unhappy dream. It is not necessary here to recount the atrocities committed by the conquerors: the murder of women and children, the burnings at the stake and other revolting tortures committed by the Spaniards on a people that had every right to defend their native soil. The entire population of Higuey was exterminated, with the exception of the chief Cotubanama, his wife, children, and a few retainers, of whose fate we have already

${ }^{2}$ Las Casas, Hist. Ind., libro II, cap. viii.

${ }^{2}$ Ibid., cap. xv. 
learned. Nor is it the purpose to discuss at greater length the history of the primitive inhabitants of this region, but merely to point out such connection as existed between Saona island, Higuey, and the district of Macao, which localities were undoubtedly inhabited by people of one tribe. The early accounts of these regions are of great interest to students of the history of early Spanish settlements in the New World, and it would be difficult to find in all history anything like the atrocious means by which the complete annihilation of the aborigines of the West Indies was effected.

\section{SaONa Island AND its ARCheOLOgy}

The island of Saona was surveyed in 1902 by the staff of the U. S. gunboat Dolphin, under Lieutenant-Commander Albert Gleaves, and an excellent chart (Hydrographic Office chart 2I06), embodying the results of the survey, was published. At the present time the island is uninhabited; but this is not to be wondered at, inasmuch as it is not fertile, it is the resort of an unbelievable number of insects, and its eastern part is completely devoid of

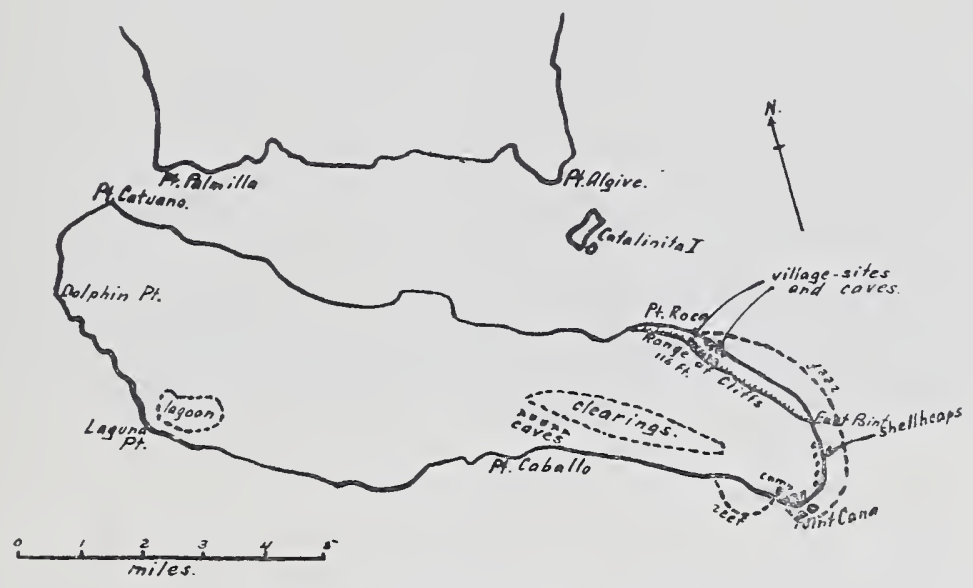

FIG. I3.-Map of Saona Island.

potable water. The author was told by fishermen who occasionally visit the island in order to find shelter for a night or to salt and sundry their catch, that in the western portion of Saona can be found a few wells, but that the water is almost undrinkable on account of the lime contained in it.

From San Pedro de Macoris, on the mainland, the author, accompanied by William Godet, a Turks Islander who accompanied 
the expedition in the caparity of handy-man, proceederl to the small fishing village of Bayajibe where a sailing ressel was chartered to take the party to a point on the southern coast of Saona, one mile to the westward of Point Cana (fig. I3). This is one of the few spots suitable for pitching a tent and establishing camp. There is a brackish lagoon within half a mile of the shore, and there is also a well the water of which can be drunk in case of absolute need. This also is the nearest available camping spot to the castern coast of

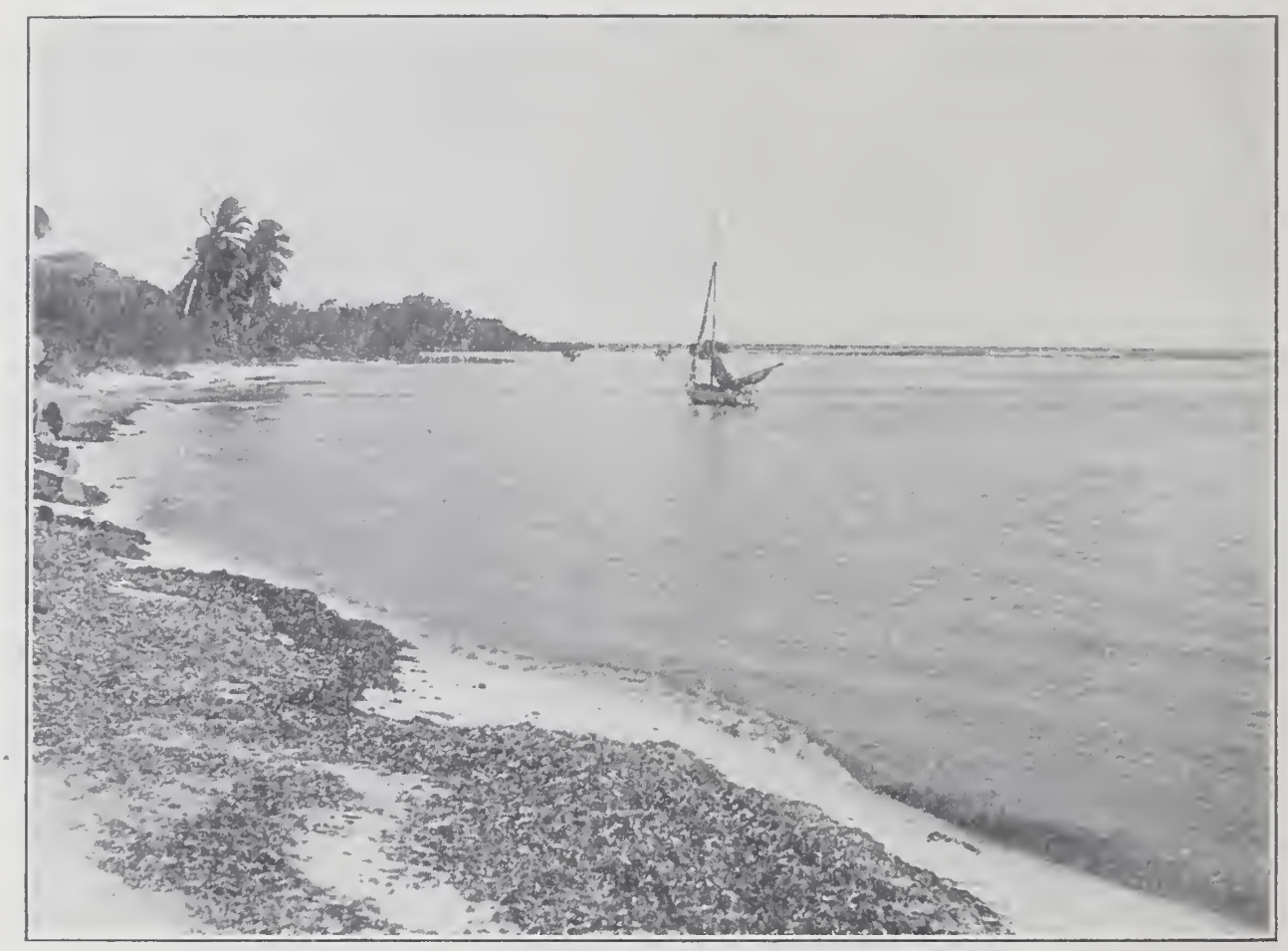

FIG. I4.--Sandy southern coast of Saona.

Saona. The entire southern coast has a sandy beach (fig. I4), while the entire eastern and northern coasts are of a coral formation (fig. I5) on which one can neither effect a landing nor erect a tent, there being neither trees of any size, nor soil. The author and his helper remained on the island sixteen days, during which time the chartered vessel called twice with a supply of drinking water.

The necessaries of life which one finds on Saona are few, an occasional wild pigeon and a fish or two.being the only articles of food that were not imported. But while food is scarce on Saona, 
so much cannot be said of animal pests, mosquitoes, sandflies, centipedes, scorpions, and a particularly vicious variety of wasp being found in great numbers on the beach and in the interior. At times mosquitoes and sandflies especially were so bad that it was impossible to enter the bush on the southern side of the island. Fortunately the greater part of the work to be done was in the neighborhood of Point Roca, where hardly any of these pests were to be found; perhaps it was for this reason that the aborigines had

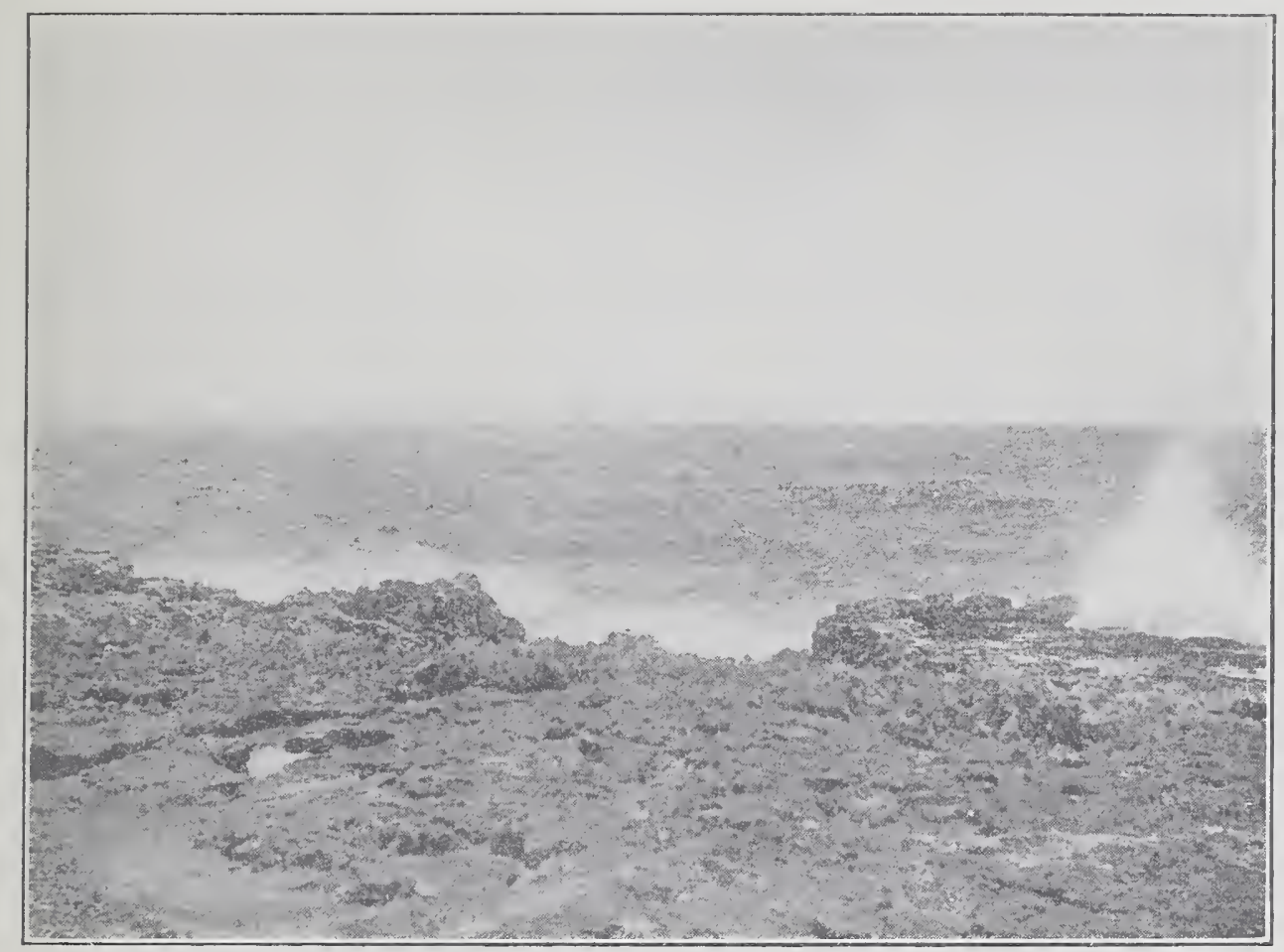

FIG. I5.-Typical coral formation on eastern coast of Saona.

their villages around Point Roca, and that they merely visited other localities to cultirate their crops, to build and keep their canoes, and to dive for conchs, an important article of food. It was often necessary for our little party to retire before sunset and not to get up until an hour after dawn, a trying ordeal when one considers that sleeping under a cheese-cloth canopy, in order to keep out the tiny sandflies, has much the effect of a Turkish bath. It was not possible to transport the tent and the rest of the camp outfit to Point Roca through the dense brush and over the honeycomb coral, 
and as there is no landing place on the eastern coast of the island, transportation by boat is out of the question.

Saona is 12 miles long and 3 miles wide, at the widest point, with an area of about 25 square miles. The rocky parts of the coast consist of the characteristic honeycomb coral, but the southern coast is chiefly a gently-sloping sandy shore. The greater part of the southern and eastern coasts is bounded by barrier reefs which are continually building up and forming new land. The bush on the eastern part of Saona is that characteristic of all West Indian coral islands, but the geological structure of Saona is different from that of the mainland, and is not unlike the Bahama islands. A great deal of the shrub consists of buttonwood, and there are also quantities of candelabra cactus and a species of small mahogany tree. The western part of the island is densely wooded, and there are said to be some valuable hardwood trees there. The interior of the eastern coast of Saona exhibits a remarkable phenomenon: the core of the island, some I 6 feet high, has evidently been suddenly pushed upward by two distinct marine upheavals in preæolian times, and, as a result, in the top of the cliffs at Point Roca one finds caves formed by the action of the waves at a period when the core of island protruded only about ten feet above sea-level. After the first upheaval, other caves were formed in the base of the rocks, now about a hundred feet above the sea, when a second upheaval forced the core of the island upward another ten feet and

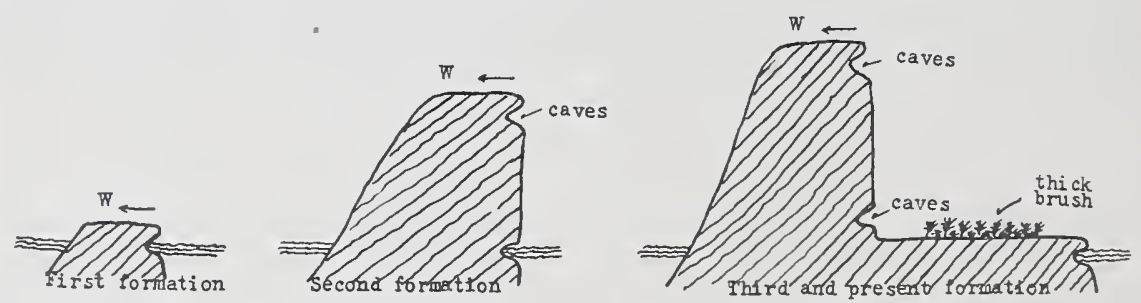

Fig. - Eastern coast of Saona at different geological epochs.

formed the plateau now found between the high rocks at Point Roca and the sea (fig. I6). It was in this second range of caves, at the foot of the high cliffs, that abundant evidence of former aboriginal occupancy in the way of sherds, broken stone implements, etc., was found. It was necessary to blaze a way through the dense brush from the coast to the foot of the cliffs, a distance varying from half a mile to a mile. 
One also finds on Saona, on a small bluff half a mile inland from the eastern coast, at East Point (see the map, fig. 13), the ancient foundation of a lighthouse that was never completed; the foundation is in good repair and could be used for a much-needed lighthouse to protect vessels coasting the shores of the Dominican Republic. No information regarding the structure could be gleaned from fisherman, but it is not unlikely that the work may have been commenced on the recommendation of Sir Robert Schomburgk, who made an extensive geographical survey of Santo Domingo in I $850-52$.

The author made daily trips from the camp near Point Cana to points along the eastern coast, but during the first three days' sojourn on the island was unable to find any indication of former aboriginal occupancy, with the exception of scattered conch-shells with typical Indian perforations. In determining, throughout the West Indies, whether the aborigines had visited certain localities, the author has been greatly aided by an examination of old conchshells (Strombus gigas) lying about. One often finds these shells in the interior of an island, sometimes as much as five or six miles from the sea; then again small heaps of the shells have been found on the coast, and they have been seen also in caves. Frequently the semi-fossilized condition of the shells indicates that they were opened in pre-Columbian times, but where the original pink coloring is preserved it is evident that they were taken from the sea at a comparatively recent date. There is one way, however, by which one can determine with certainty whether the shell was opened by a prehistoric or a post-Columbian inhabitant, and that is the condition of the aperture by means of which the conch was loosened from its shell and the meat extracted. If the aperture is a small round one (fig. 17 ), it is certain that the conch was opened and used by an Indian. The author has asked many West-Indians how the conch could have been taken from its shell in this way, as the hole is far too small to admit the introduction of an instrument like a knife to loosen the muscle from the inner convolutions. The modern conch-fisher makes either an elongate orifice in the shell of the type shown in figure 18 , and then with a knife-blade loosens the muscle, or else with a hatchet-knocks off the entire top of the 
shell. After the muscle has been cut loose, the soft conch can be pulled through the mouth of the shell. No negro conch-fisher with whom the writer has ever talked, could explain how an Indian could have extracted a conch by making merely a small round hole, hence the process can be explained only by the theory that the pre-Columbian inhabitant caused the conch to release its hold on the shell by pouring boiling water in the aperture. Whatever the value of this conjecture, it is a fact that the difference in the apertures is an important guide in determining where the aborigines lived, and has proved of great value in our West-Indian explorations.

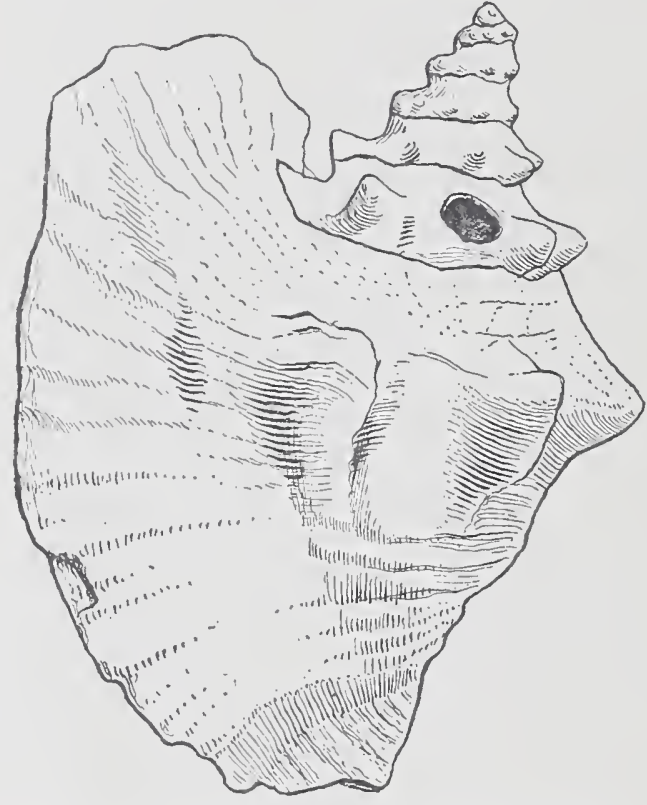

FIG. I7.-Conch-shell opened by an aborigine.

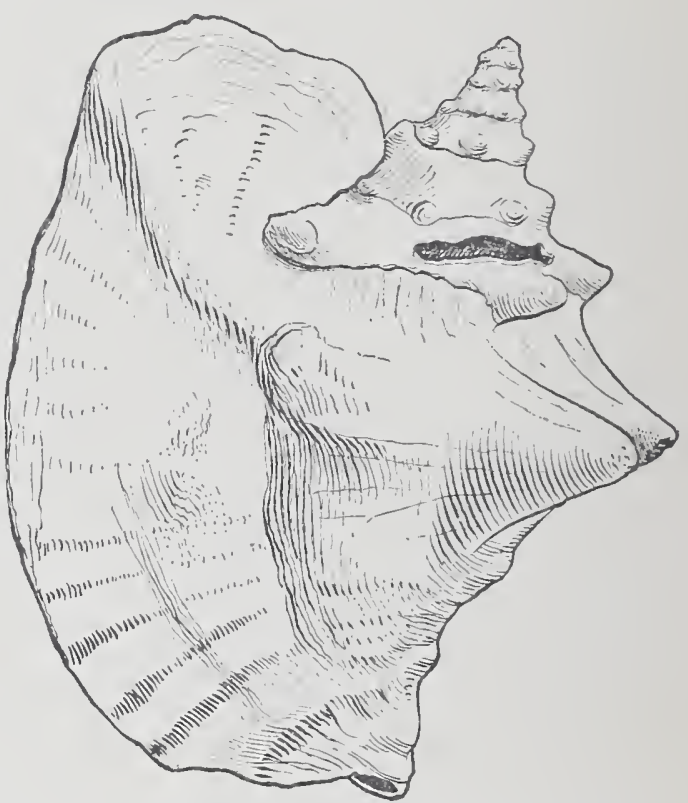

FIG. I8.-Conch-shell opened by a modern negro conch-fisher.

From Cuidado reef, at the extreme southeastern point of Saona, to a point half-way to the inland bluff called East Point, a distance of about a mile, one encounters, at no great distance from the sea, small heaps of conch-shells, and as no indications of an Indian village-site in the immediate vicinity is found, it is evident that the Indians came to this spot only to collect the conchs on the rocky shoals between the reefs and the beach, then to extract the meat from the shells, and to carry it, possibly after salting, to their habitations. Extensive excavations in some of these small heaps of shells mixed with brain coral (fig. I9) failed to produce potsherds or other artifacts. 
The explorations were extended day by day farther to the north along the eastern coast, when finally, in cutting a path through the brush almost due west from a point on the beach about half a ilem from Point Roca, we found, at the very foot of the cliff, a large quantity of potsherds and some fractured stone celts (figs. 20, 2 I)

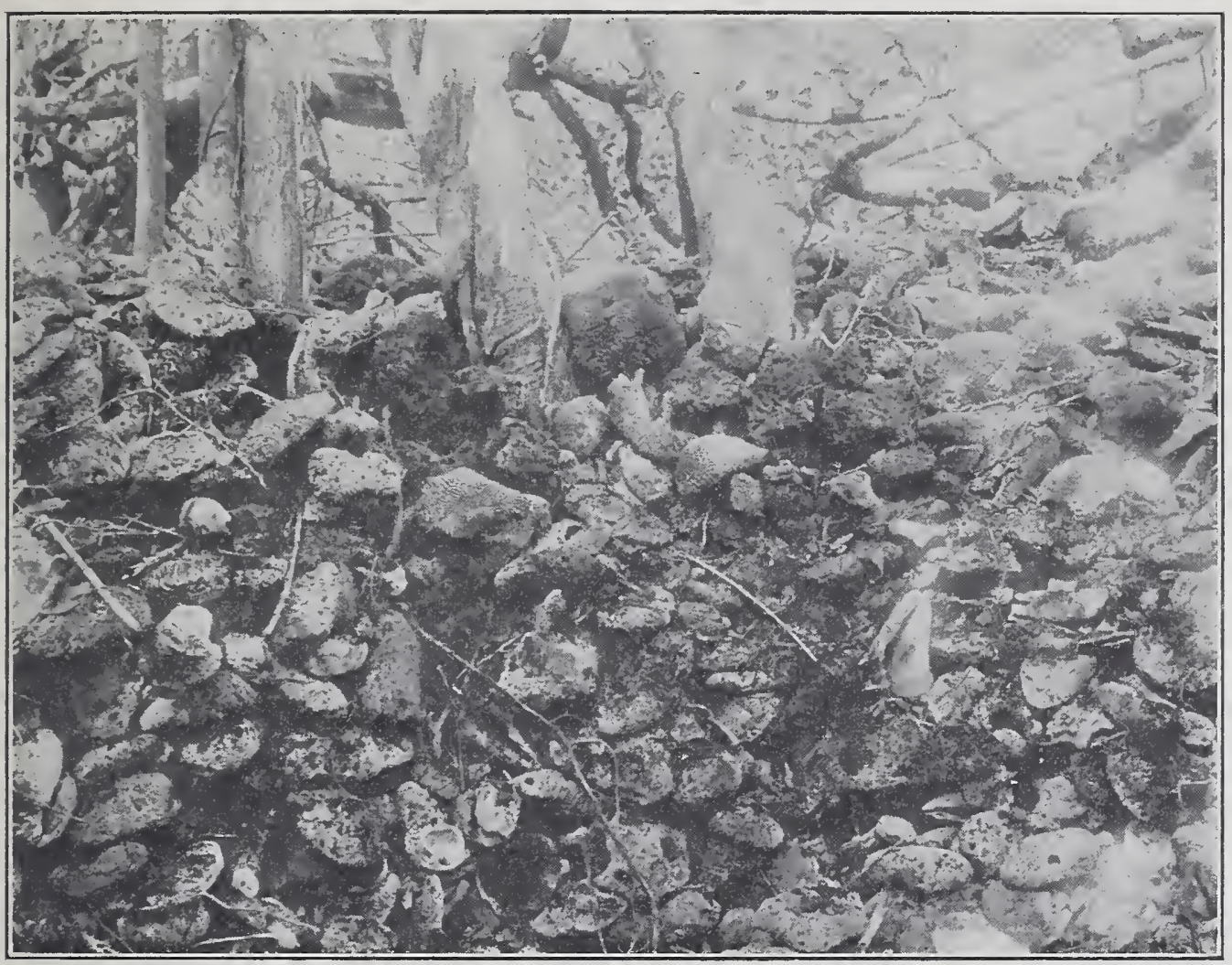

FIG. I9.-Deposit of conchs and brain coral.

As abore stated, the cliffs at Point Roca, at a distance of half a mile to a mile from the shore, rise perpendicularly from a plateau about ten feet above sea-level and which is densely covered with brush through which one has to cut his way with a machete. The survey map above mentioned gives the actual height of Point Roca as I 6 feet above sea-level. The cliff slopes gradually to the southward and still attains a height of about roo feet at a distance of two miles from the nor theasterly extremity of Saona. It is impossible to scale these cliffs directly at Point Roca, but half a mile from Point Roca, ascent is possible, though dangerous and difficult. The limestone is greatly weathered, and the rough surface, combined A.I. A.тн., x. s., x7-6 
with the small cacti which have found a hold on the almost sheer face of the cliffs, makes climbing an unpleasant task. No evidences of Indian occupancy were found on the high plateau; but this lack is not to be wonderch at, since the vegetation is almost impenetrable and the rock formation such that walking is impossible. At the foot of the cliffs are a great many shallow caves, or, rather, overhanging shelves of rock. Caves are found also at the top of the cliff, but these are not accessible. After climbing the cliff, the author

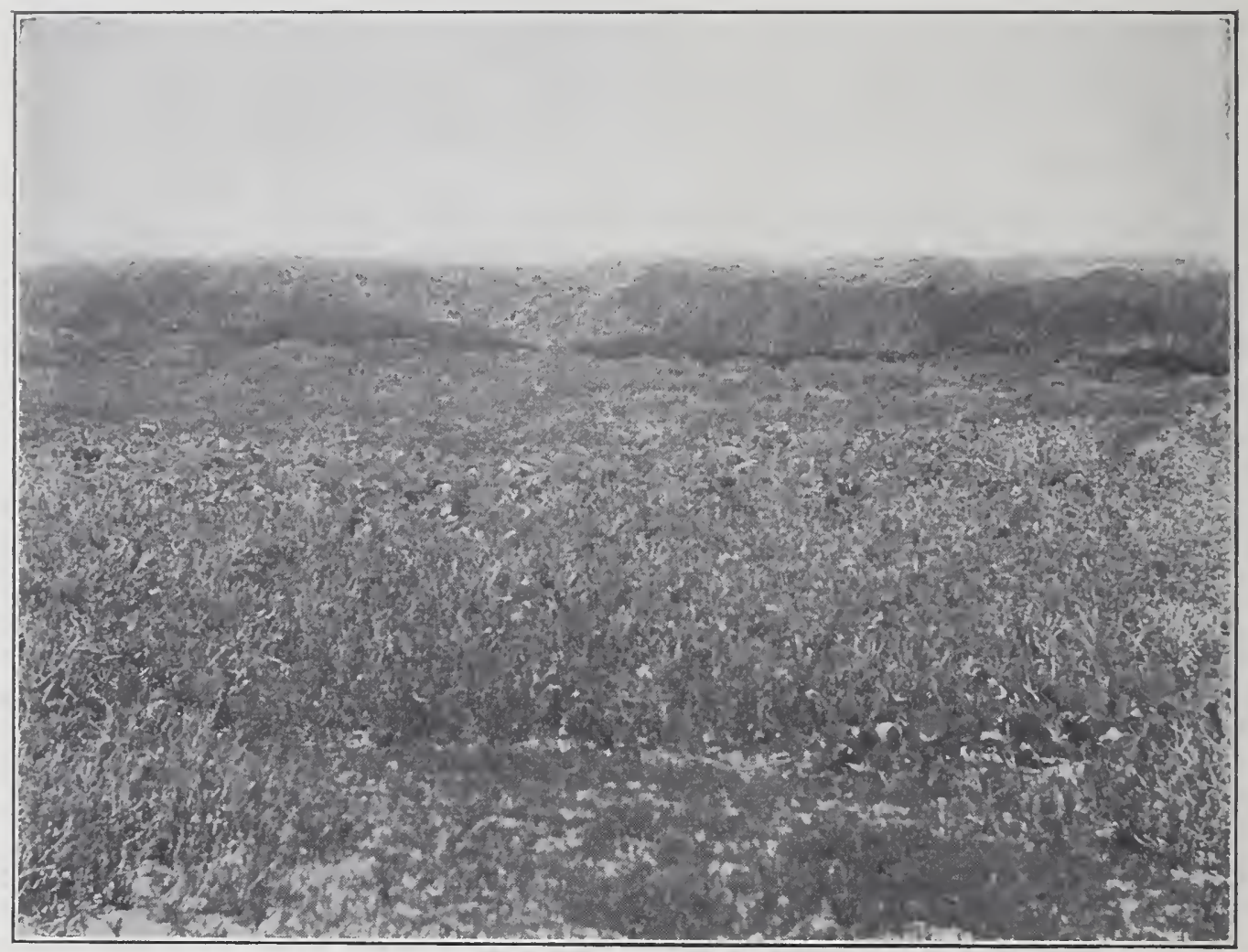

FIG. 20.-Dense brush between beach and inland cliffs.

attempted to descend into one or two of these caves with the aid of a rope, but as this was found to be impossible, the theory that the upper range of caves was used by the aborigines for any purpose may be dismissed as untenable.

Potsherds, chiefly fragments of cooking vessels, were found in several of the caves at the foot of the cliffs, but nothing was found to prove that these shelters were used for habitation, for burials, or as shrines. The sherds found here may be parts of 
vessels left in the caves to collect water from the drip of stalactites. As previously mentioned, a large quantity of sherds was found at the foot of the cliffs outside of the caves, over an area of about two miles in length and about fifty yards in width. It might therefore well be that the aborigines had a village at the foot of the rocks and stationed sentinels on the summit to guard against invasion by enemies, and that in case of severe storms the inhabitants sought shelter in the numerous cares and under the shelving rocks.

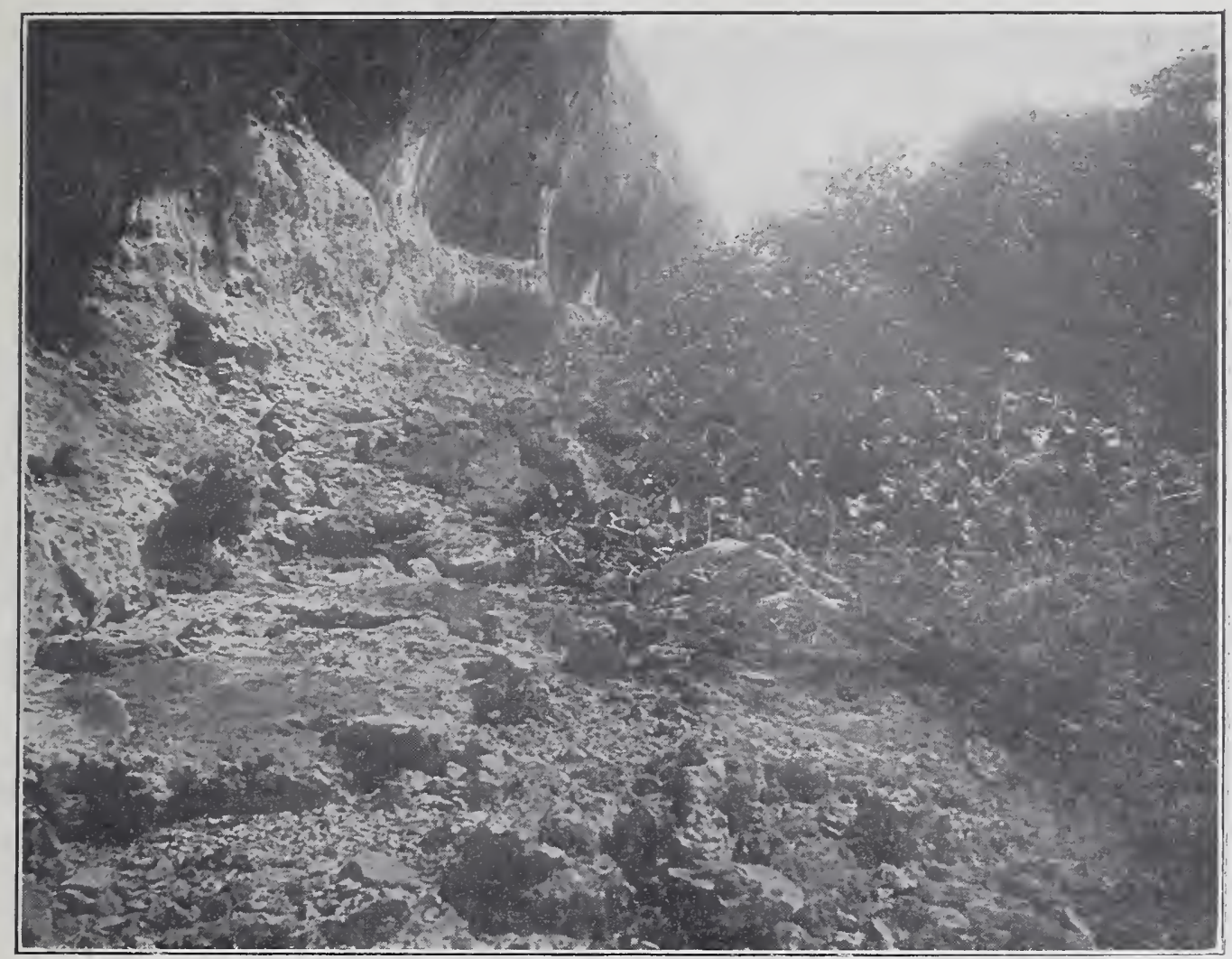

FIG. 21.-Foot of inland cliffs and cares.

It cannot be said that the inhabitants of Saona were troglodytes, principally because in the caves explored in the interior of Saona: no indication of Indian occupancy could be found. One of the: most noteworthy finds among the potsherds collected along the: base of the range of cliffs was a new type of neck of a water vessel, subsequently found in large numbers in the caves of the Macao district. This sherd possibly indicates that the aborigines of Saona. were in the habit of going to some inland well for their drinking water, 
since no potable water can be found within a radius of three miles from Point Roca, unless one excepts the drip, negligible in quantity, from the cliffs and the stalactites. It may also be stated that practically no shells were found in the area where the potsherds occurred, and that twelve broken petaloid celts were collected, of the usual Antillean type, but no entire ones were found.

No kitchen-middens were met with on the eastern part of Saona, but this condition is not unusual on these soilless coral islands. It is possible, however, that one might find middens and village-sites on the western half of Saona, because the presence there of large trees would indicate a supply of soil that preserves the hummocks upon which the Indian habitations were built and their accompanying refuse-heaps accumulated. It is hoped that further researches in the western part of Saona will be conducted.

Another village-site was found due east from the site under the rocks, within 20 yards of the shore. While not covering so extensive an area as the first site, a large quantity of sherds was collected, notably a number of the typical pottery heads of the general region.

Extended explorations were conducted also to the westward from the camp at Point Roca, especially in the interior and through the brush. The author was guided to some inland caves by visiting fishermen, but could find no remains in any of these.

While it is not desirable to theorize on the means employed by the Indians to protect themselves against the insect life found on Saona, one can picture the mode of life of its early inhabitants. It is known that their principal settlement can have been at no other place than the foot of the cliffs of Point Roca, judging from the occurrence of the large number of potsherds there; that they went along the shore to the southward to collect conchs, their chief food staple, and that undoubtedly they also caught fish on the shoals surrounding this part of the island. They doubtless stored their canoes on the southern beach, the only place where they could have effected a landing, as previously mentioned. There is no question that the Indians went to the interior to cultivate cassava and other vegetables, as this was not possible in either the rocky ground of the eastern coast or the sandy soil of the south. It may also be said that at practically all seasons the aborigines were prevented 
from living in the interior, on the southern coast, and on such parts of the eastern coast as provided their supply of sea-food, owing to the innumerable mosquitoes and sandflies. These conditions, therefore, may have led to the selection of Point Roca as the most suitable abode, since this point is exposed to the southerly, easterly, and northerly winds (as may be known, there is no westerly wind ten times a year in the Antilles), and where in consequence mosquitoes are scarce and sandflies not found at all.

Whether or not the utia (Capromys) ever existed on this island is not known, but from the fact that skeletal remains of this animal were found in the kitchen-middens of the mainland, at Point Barbara, it is probable that it occurred also on Saona, although no bones were found on that island, possibly due to lack of soil. There are three species of non-venomous snakes on Saona.

In concluding this short report of investigations on Saona, it may be said that it is practically impossible to remain on this island for a considerable time without danger of serious illness from the stings of insects. In consequence it was deemed best to conclude the Saona work and to be contented, for the time being, with the exploration of the eastern half of the island, trusting at some future time to be able to explore the western portion by means of a vessel which at night could anchor far enough off-shore to be out of range of mosquitoes and sandflies. It will also be noted that in a later part of this paper no mention is made, nor illustrations given, of the potsherds collected on Saona. This is for the reason that in the explorations at Cape Macao so many sherds of similar type, but in better state of preservation and of larger size, were found, that the illustration and description of these apply to the Saona specimens as well.

Investigations near Salado and Cape Macao

After leaving Saona, the author returned by the chartered sailing vessel to the fishing village of Bayajibe, where a pack-train was hired to conduct the party and its equipment to the pueblo of Higuey in the interior. From Higuey the author continued across the island to the cacao plantation of $\mathrm{Mr}$ F. Goussard, a French settler in this district, who generously placed his house at the disposal of the expedition. Mr Goussard's plantation is near Salado, 
On the Anamuya river, about four miles from Cape Macao on the coast. While this gentleman was not residing on his property at the time, the author was fortunate in finding there Major Daniel Tenaille, a young Frenchman who had bought land in the neighborhood and who was stopping at Mr Goussard's plantation. The author takes this opportunity to extend his thanks both to Mr Goussard and to Major Tenaille for their hospitality and many courtesies during his stay in Santo Domingo, especially to Major Tenaille for the specimens found on his property and given by him to the Heye Museum.

The party spent three weeks at the house of Mr Goussard, and a similar period on the plantation of Major Tenaille. During this time we were enabled to explore thoroughly the Macao district and to conduct excarations at various sites. The usual mode of travel was on horseback, and comparatively good horses could be obtained for this purpose.

On Major Tenaille's plantation and the adjacent property it was our good fortune to find several caves which evidently had remained undisturbed since the annihilation of the aboriginal inhabitants. These caves are found in the midst of a virgin fcrest, within an area of a square mile (fig. 22). There can be no doubt that all these caves would be found to communicate, if one cared to open the tunnels which at present are too small to allow the passage of a human body. In the accompanying photograph (pl. Iv $, a, b$ ) are shown the mouth and the interior of the first chamber of one of these caves. In all, eight caves were found, the openings sometimes being hidden in the dense forest, making it difficult to relocate them after they had once been left. Pottery was found in all these caves.

The caves explored are in the typical limestone formation of the West Indies. Two of them are quite large, and contain underground lakes of fresh water. It was in these two caves that the greater part of the pottery was found. Practically all of this earthenware was broken, due in part to the falling of slabs of limestone from the roof, and partly from having been thrown about by the original occupants; for example, in two instances parts of a vessel were found separated by a distance of ten yards or more. 


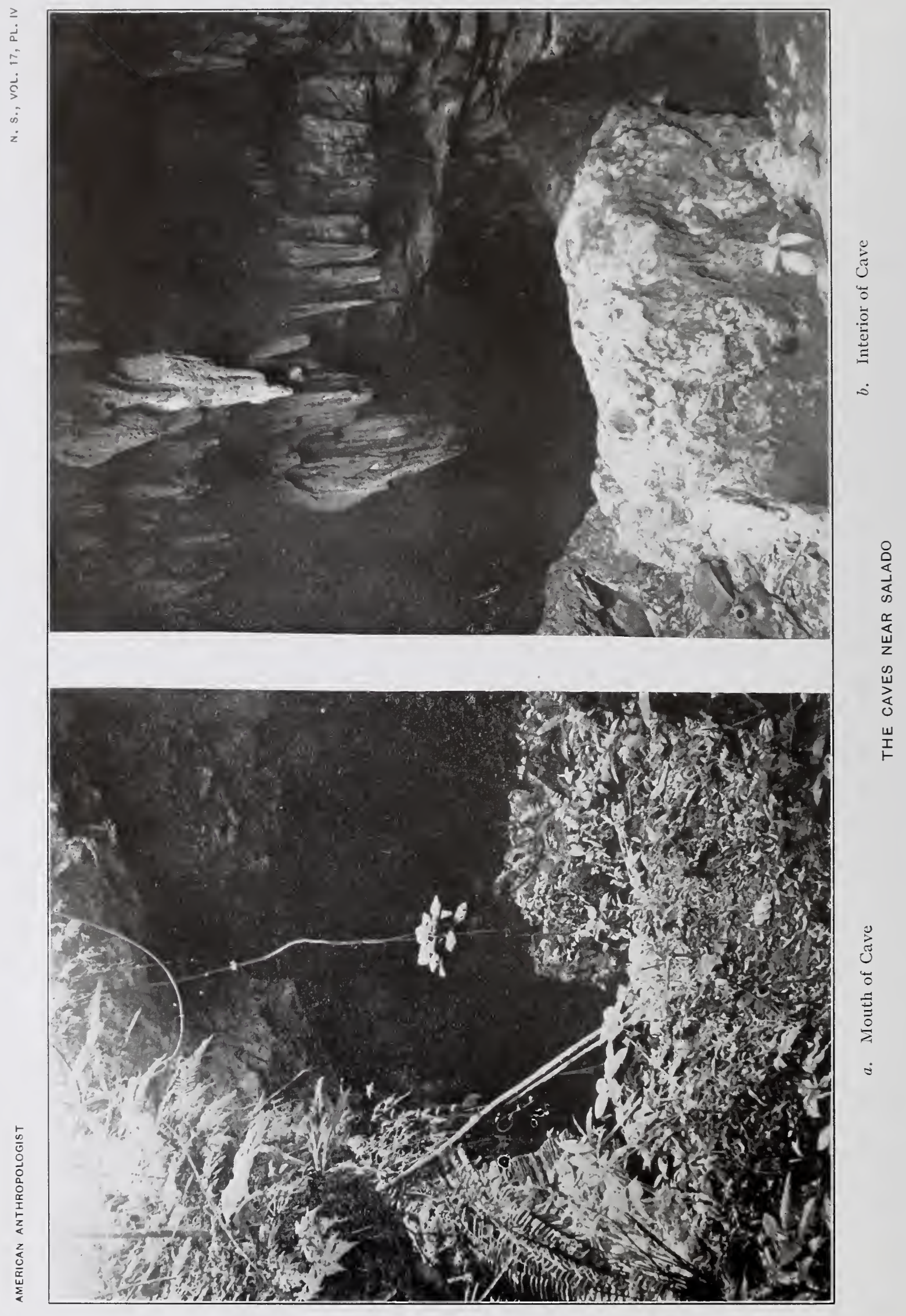


There is every reason to believe that these caves had not been entered since the advent of the Spaniards, as they open on land that had been cleared only after Major Tenaille bought the property, and even then it was impossible to persuade the Dominicans of the laboring class to enter the cares unless accompanied by cither

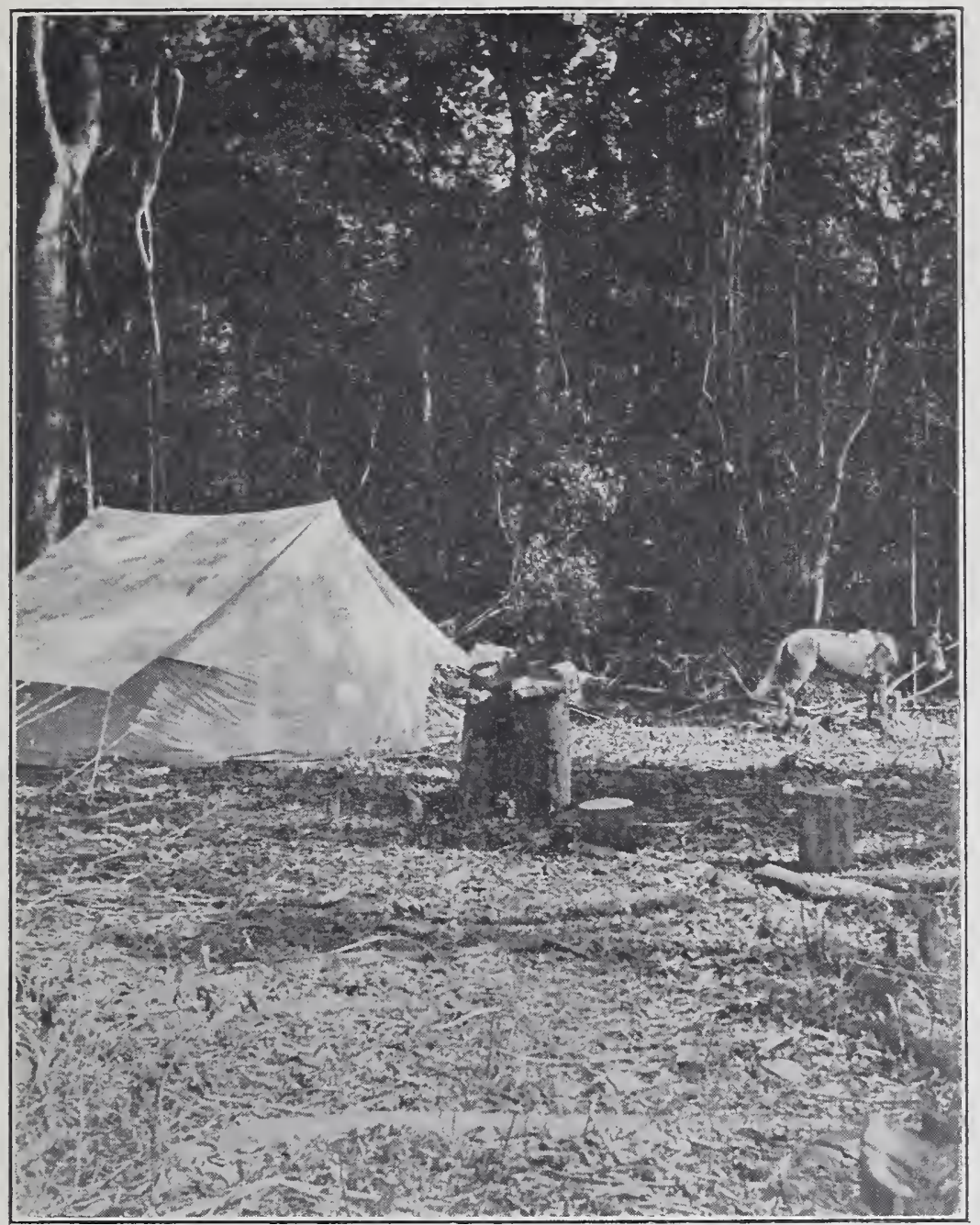

FIG. 22.-Camp near Salado, in the neighborhood of the caves.

Major Tenaille or the writer. In the two caves with the underground lakes a great many potsherds were lying in the water, some of which were recovered by diving on the part of Major Tenaille, the author, and Godet, our colored helper. A fragment in the lake bottom, in some places twelve feet in depth, was first located by burning a piece of magnesium wire; a long pole was then put in the 
water alongside the sherd, and the diver, following the pole with one hand, recovered the pottery with the other.

Most of the sherds found were lying between the bowlders that cover the floor of the caves, and which, in the course of centuries, had fallen from the roof. Between these bowlders are small chambers and tunnels, making the thorough exploration of a cave a tedious task of several days. One cave especially was hard to explore, owing to the dense air in the bottom which made breathing difficult. The entrance of this cave has a downward slope of about forty-five degrees, and the lakelet at the bottom is not less than thirty feet lower than the mouth.

Chemical analysis of water from the care lakes, made by $\mathrm{Dr}$ Frederick W. Zons, to whom the author wishes to acknowledge his indebtedness, indicates 975 parts per million of mineral matter, of which $55^{\circ}$ parts are sulphates, and $2 \mathrm{I} 6$ parts oxide of lime present chiefly as sulphates. The mineral matter contains, in addition, considerable sodium sulphate and chloride, also 36 parts per million of iron and aluminium oxides, and 33 parts per million of silica $\left(\mathrm{SiO}_{2}\right)$. The water contains also IoIo parts per million of organic matter, but this of course may be of recent origin. The water is extremely unpalatable, and the author drank it only when his supply of rainwater was exhausted. The horses and mules refused to drink it, even after they had been without water for two days.

As has been said, the area in which these caves are found does not exceed a square mile. Taking this area as the limit of investigation, the author attempted to find the exact location of the Indian village-site, which presumably was within a short distance of the water supply. While odd fragments of pottery were found in the undergrowth within a radius of two miles of the caves, in no instance were they discovered in sufficient quantity to enable the exact determination of a former settlement, hence it cannot be said definitely that the Indians had a permanent abode in this vicinity. Furthermore, in view of the quality of the cave water, and the fact that typical village-sites and kitchen-middens are not found along the coast within a distance of eight miles from the cares, it is probable that the aborigines came to these parts only in the planting season, during which time they lived in temporary shelters. 


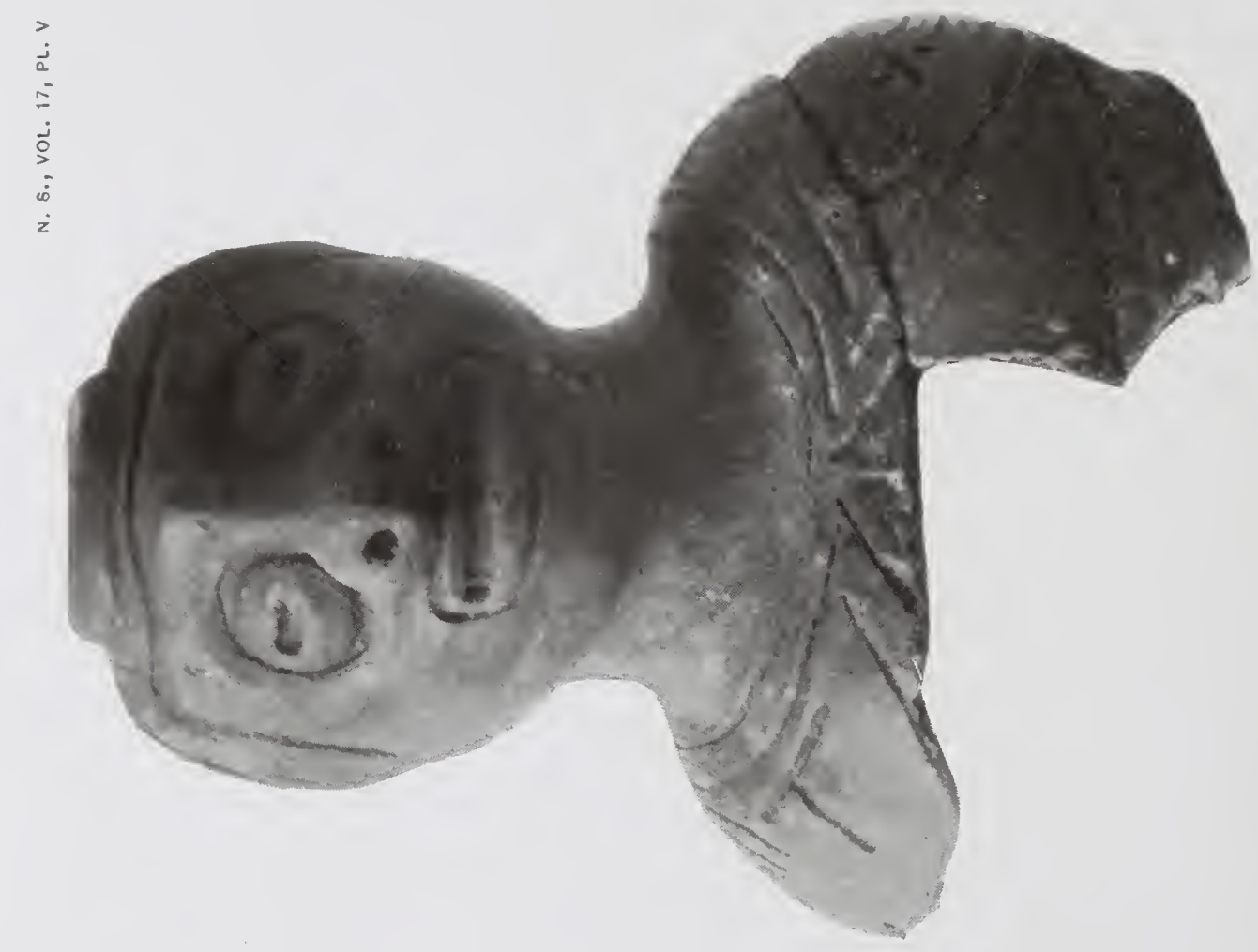

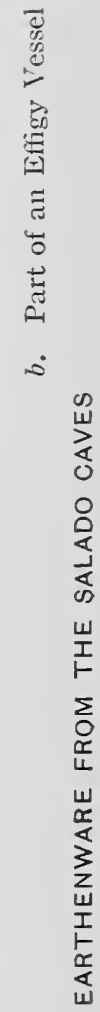

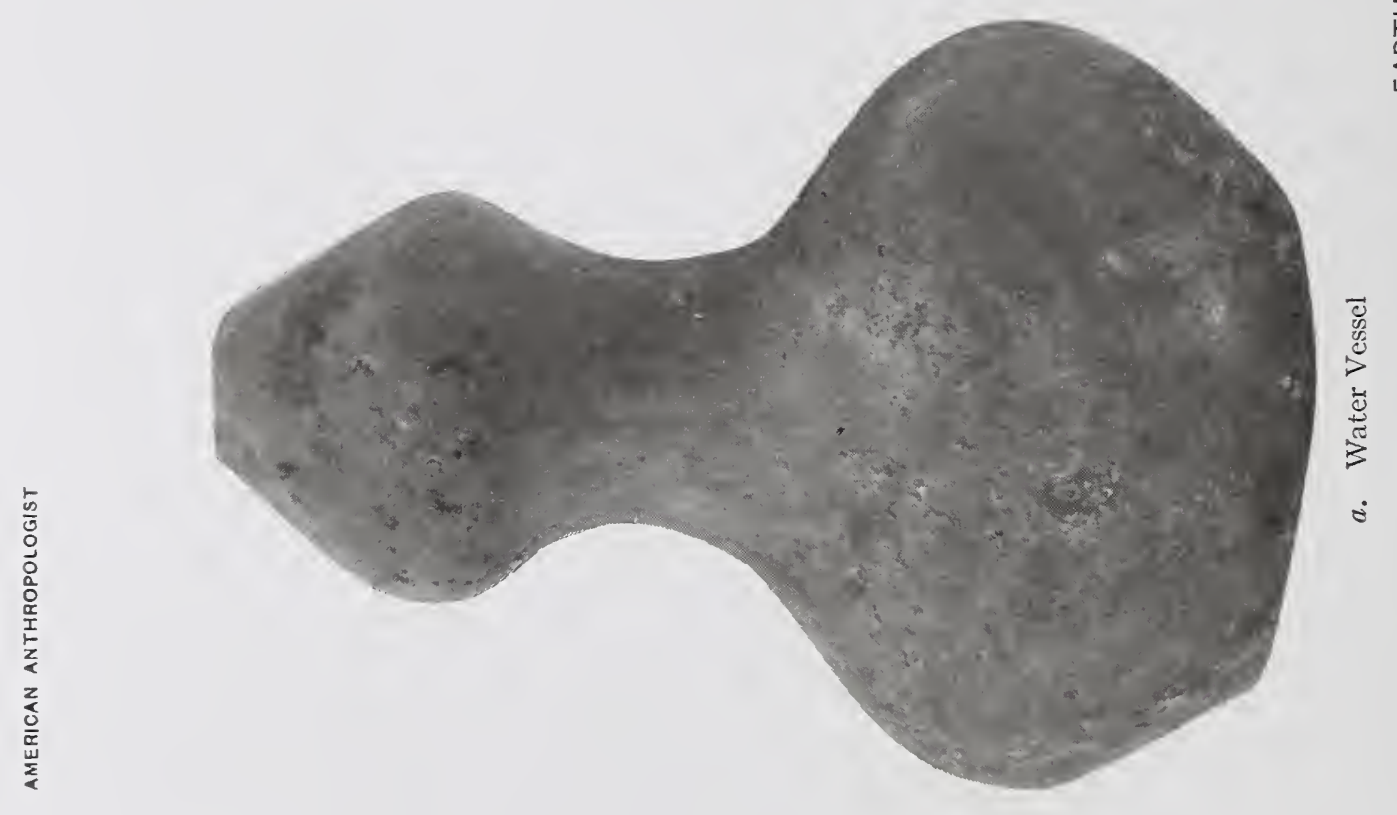


The month of April, I9I4, was likewise spent in the Macao district, with headquarters in the new house of Major and Mrs Tenaille, by whom the author was hospitably entertained. As in the case of the first expedition, much of the success of the second visit to this region was due to Major Tenaille, who had obtained from the natives much valuable information for the use of the author in the interim of his two expeditions. The caves were again visited, and a new range of caves was explored in the Peñon de la Vieja Rufina, near Cape Engaño. The Bonao district was also reconnoitered with the view of future work in the inland district.

\section{Description of the Pottery}

Perhaps the most interesting potsherd from the Salado caves is the top of a water vessel seemingly designed to serve as a filter. This fragment was found among the bowlders covering the sloping floor of one of the caves, and on careful examination several large pieces of charcoal were found in proximity to the sherd. Figure 23 shows the fragment in an upright position, while figure 24 pictures

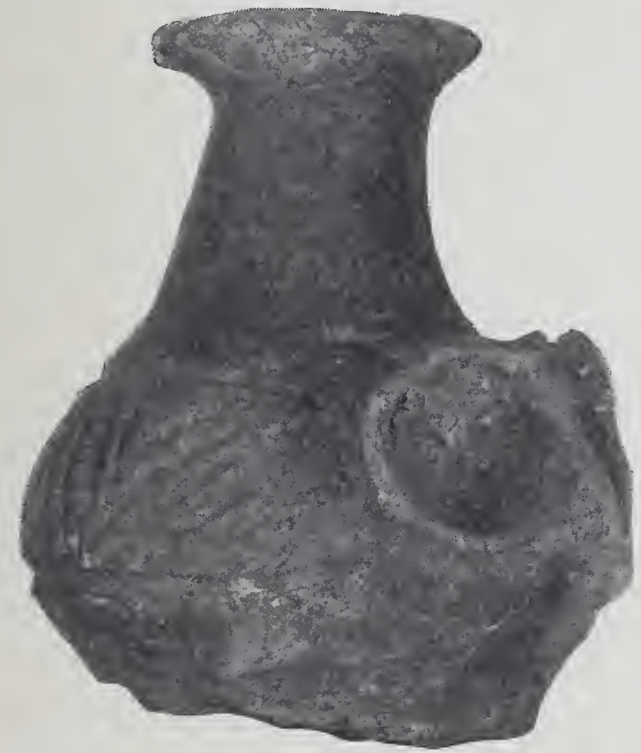

FIG. 23.-Top of "filter jar."

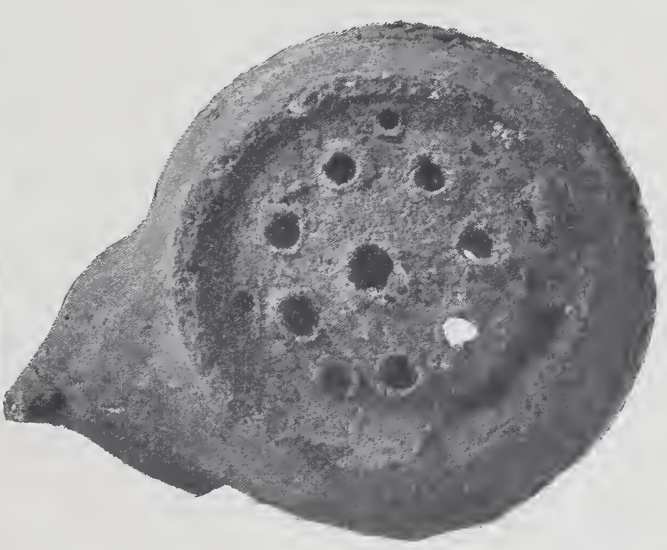

FIG. 24.-Bottom view of "filter jar."

the bottom of the specimen. In the latter illustration the "filter disk" can plainly be seen, dividing the upper part of the vessel from the lower, and figure 25 illustrates the probable appearance of the original vessel and the use to which it was put. The author 
knows of no other specimen of this type, with the exception of one, also from the Salado caves and kindly presented by Major Tenaille to the Heye Museum; it consists only of the disk of a "filter jar," with the perforations, but shows clearly that it is of the same type as the specimen illustrated. The author considers it

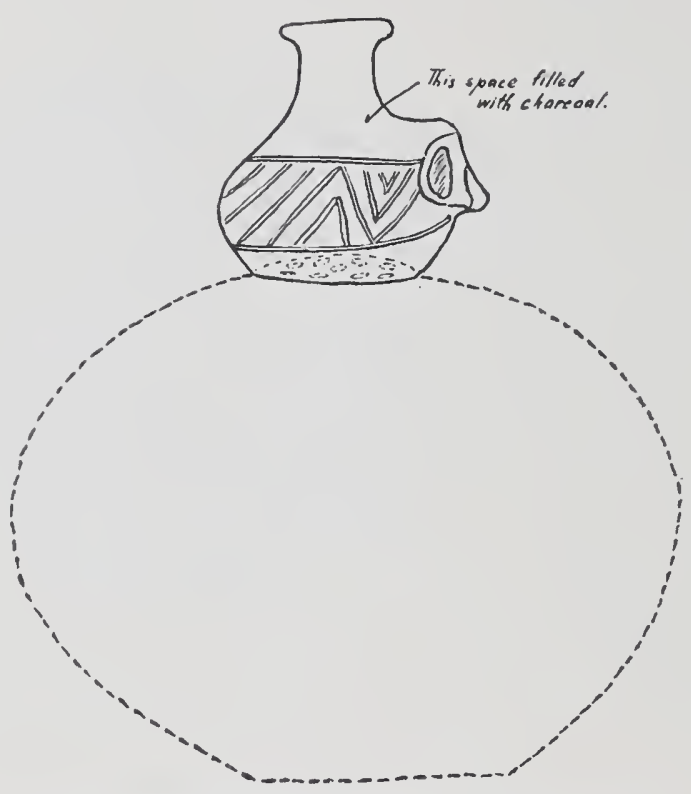

FIG. 25.--Probable outline of "filter jar." remarkable that the aborigines of Santo Domingo should have known the principle of filtering water through charcoal. It is difficult, however, to conceive what good it did the pre-Columbian inhabitants of Salado to filter their water through charcoal in this manner, as this process would not remove the lime, and the cave water does not contain other impurities necessitating its employment. The sherd illustrated is of yellow-brown clay, with a band of incised lines ornamenting the body and a conventionalized parrot-head serving to decorate one side. Height of specimen, $4 \frac{1}{8}$ inches (I0.5 cm.).

What must originally have been a well-constructed effigy vase is shown in plate $\mathrm{v}, b$. Unfortunately the remainder of this excellent vessel was not found, otherwise it would rank as one of the most remarkable vessels from the West Indies. It is more than probable that the bottom part of this vase was globular and that it joined the effigy at the remaining edge of the under side. This vessel, which is of dark-brown clay, is of good workmanship and excellent finish. The details of the head are well executed, the nose, nostrils, eyes, and mouth being prominently shown, while the ears are fashioned in a conventionalized manner with incised circles. There is a slightly elevated ridge on the crown of the head, surrounding a circular opening which served for filling and emptying the contents. The upper part of the body, below the neck, is decorated with an 


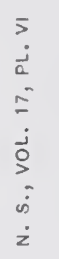
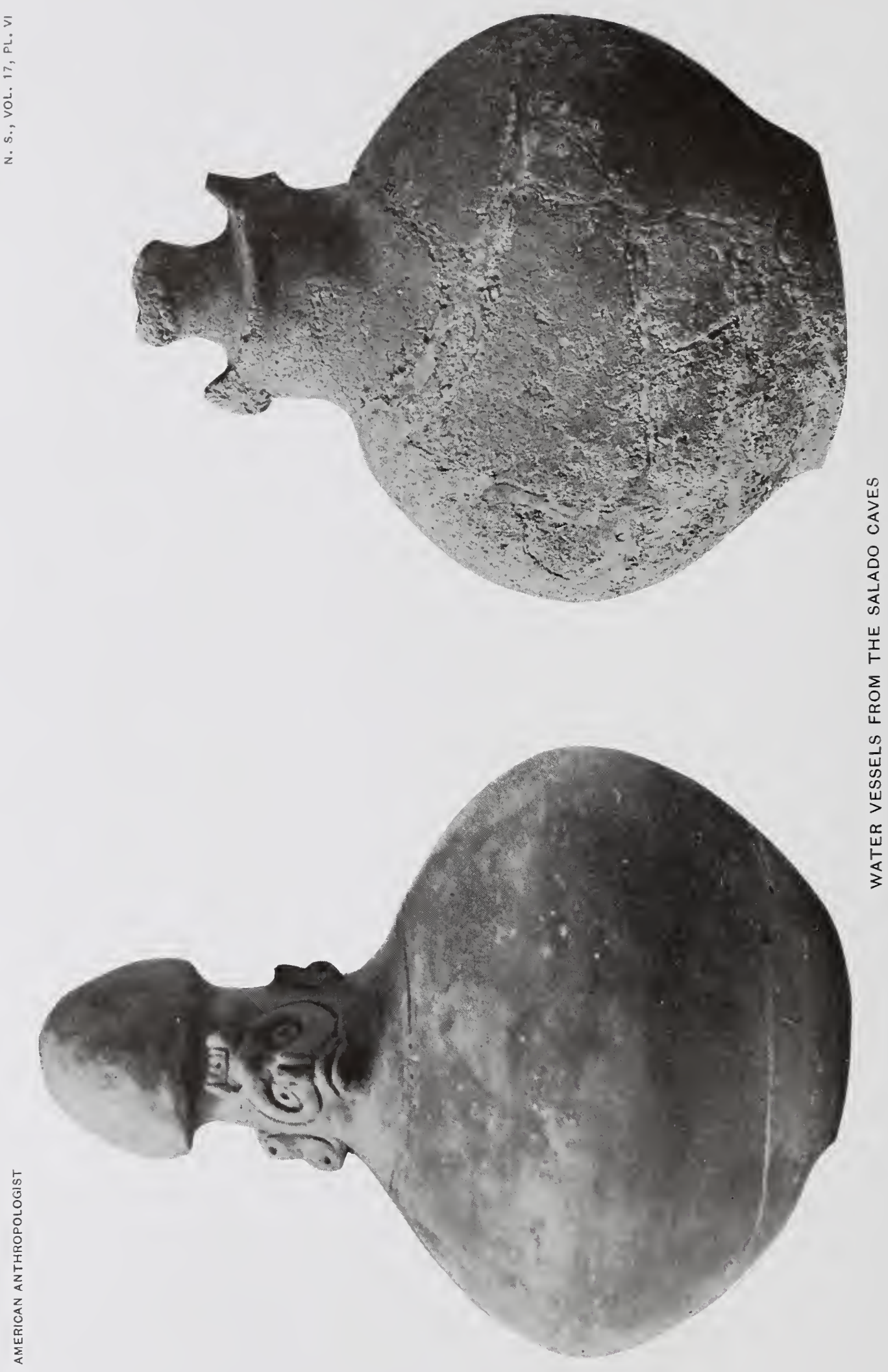
intricate, symmetrical, geometrical design which reminds one of that seen on the backs of wooden stools (duhos) found in certain parts of the Antilles, especially on the Caicos islands and the Bahamas. ${ }^{1}$ Height of specimen, 7 inches $(17.8 \mathrm{~cm}$.).

One of the few entire vessels found in the Salado caves is shown in plate vI, $a$; it is of reddish-brown clay, is well finished, and in an excellent state of preservation, having only one small hole in the side. It was probably on account of this hole that the aboriginal owner discarded the water-jar, and, instead of breaking it to pieces, as appears generally to have been done, it was deposited between bowlders, where it was found by our party. The lower portion of this vessel, when found, was somewhat incrusted with a calcareous deposit, occasioned by the drip of the limewater from the roof of the cave. The top part of the neck of this ressel has a somewhat conical enlargement; the lower part is decorated with a grotesque head which, judging from the sunken eyes, may have been intended to represent a monkey, a not unusual feature of decoration in Antillean pottery. Eyes, nose, nostrils, and mouth are clearly shown by deep, incised lines and circles, and the top of the head is covered by a raised, cylindrical ornament with incised decoration. The ears appear to be divided into halves, with a deep pit in each half. On the reverse side of this lower portion of the neck of the vessel can be seen a convolute design in high relief, probably representing a snake. Two parallel incised lines surround the base of that portion of the vessel where the neck merges into the globular body: these lines are half an inch apart, and the space between is divided into four equal parts by four rectangular lines joining the two circles. In each of the four spaces thus formed, the potter cut another line parallel with the two circles and at an equal distance between them. This line in each case is almost a quadrant, and terminates at each extremity in a shallow pit made with the instrument with which the incised line was cut. Height of specimen, I4 inches $(35.6 \mathrm{~cm}$.).

The three necks shown in plate VII, $a, b, c$, belong to the same type of vessels as that illustrated in plate VI, $a$, and show varied ornamentation.

1 Otis T. Mason, "The Guesde Collection of Antiquities in Pointe-a-Pitre, Guadeloupe, West Indies," Smithsonian Report for I884, fig. 202d, p. 828 . 
Specimen $a$ is a highly conventionalized head, showing only the outline of the face in a raised band; it has oblique eyes and a perforated nose. Height of specimen, 5 inches $(\mathrm{I} 2.7 \mathrm{~cm}$.).

Neck $b$ is more elaborate: the spout is ornamented with a design of incised circular lines, terminating in shallow pits, after the usual Antillean fashion, which possibly represents a type of head-ornament. The face is fairly-well fashioned, with slightly oblique eyes and two very prominent nostrils. The ears, like those of the vessel shown in plate VI, $a$, are divided into halves and have a shallow pit in each half. Height of specimen, 4 inches $(10.2 \mathrm{~cm}$.).

The third specimen $(c)$ differs slightly in that the neck is more elongate and the head is modeled in higher relief. The ears are of the same type as those of specimen $b$, and the eyes and mouth are represented by deeply incised lines. The nose stands out prominently from the face. Height of specimen, $5 \frac{3}{4}$ inches ( $14.5 \mathrm{~cm}$.).

A simple water vessel, derived from the gourd, or calabash, can be reconstructed from the sherd shown in plate viII, $a$. This specimen is of light-brown clay, is well modeled, and is without ornamentation. Height of specimen, $4 \frac{1}{2}$ inches (II.4 cm.). The gourd motif appears to be the fundamental form of the ancient water vessels from Santo Domingo.

The tops of more elaborate vessels, of which the form of the body is derived from the gourd, are shown in plate viII, $b, c, d$, and in figure 26. These sherds may be described as belonging to the doublegourd type of vessels, the body of the jar representing one gourd, while the top simulates a smaller gourd superimposed on the larger one. This is especially noticeable in plate viII, $c$, a sherd decorated -also with two monkey-heads which served as lugs or handles. This specimen is $51 / 2$ inches $(13.9 \mathrm{~cm}$.) in height.

Plate VIII, $d$, is part of a highly decorated vessel, the spout of which is lacking. The upper part of the neck is ornamented with a series of geometrical, incised lines, and also with two highly conventionalized heads which served as handles. Height of specimen, 6 inches (I $5.2 \mathrm{~cm}$.).

Plate vIII, $b$, exhibits a sherd of similar design, with two conventionalized heads and a raised band forming a $\mathrm{V}$-shaped decoration on each side of the neck. Height of specimen, 6 inches (I5.2 cm.). 


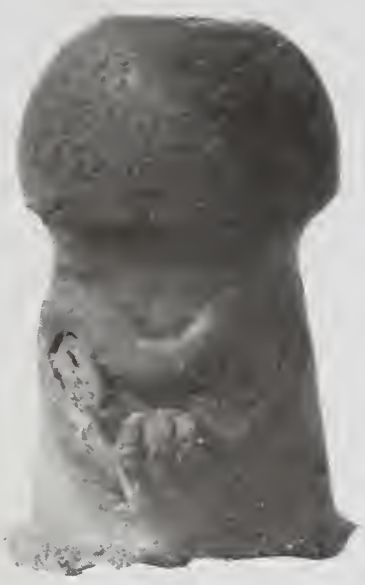

$a$

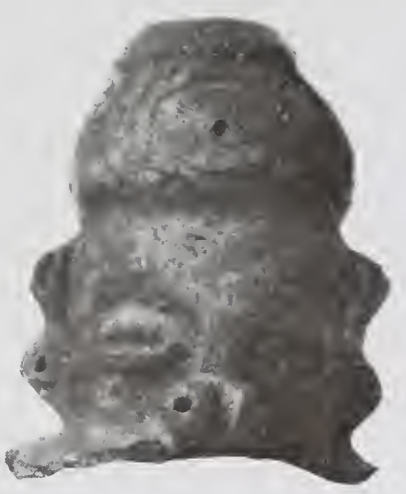

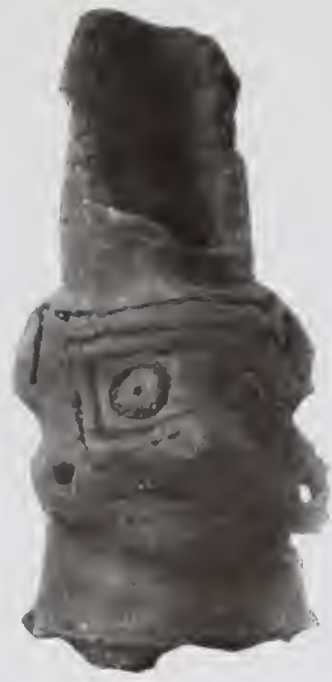

Spouts of Water Vessels

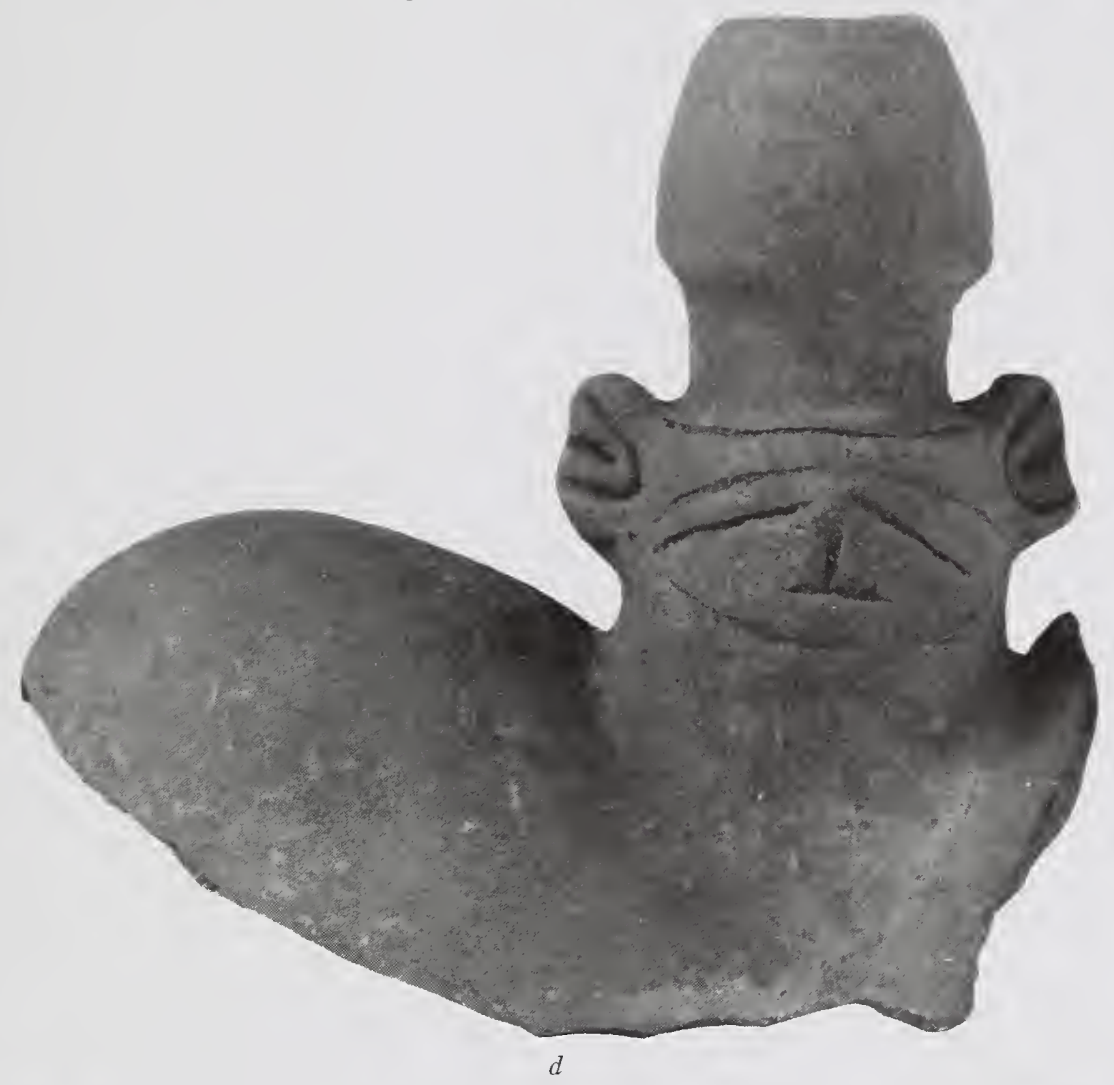

Neck of "Mammæ type" of Vessel

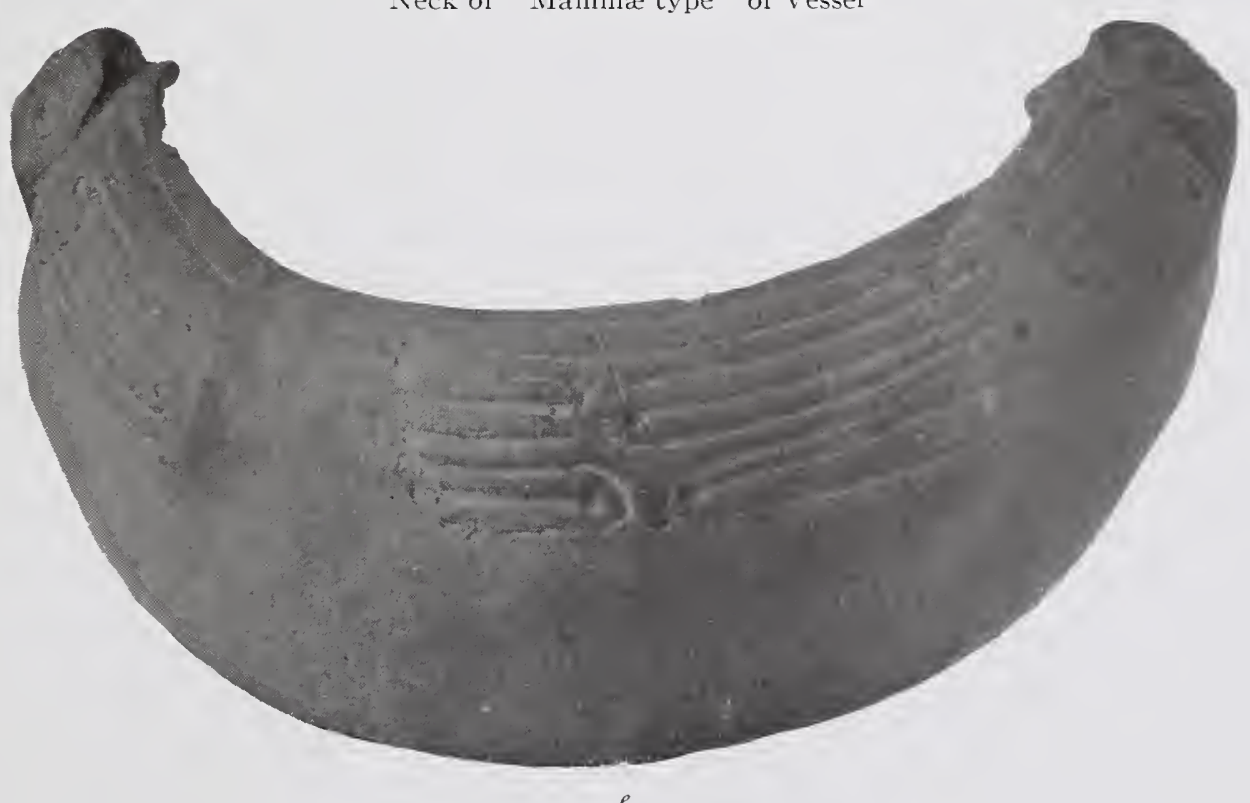

Fragment of Food Bowl

POTTERY FROM THE SALADO CAVES 

Figure 26 illustrates another highly decorated neck, with straight-line and circular incisions, and two conventionalized heads. The spout of this vessel terminates in a somewhat conical enlargement, like that of plate vI, $a$. Height of specimen, 7 inches (I 7.8 cm.).

Another type of jar was found, having a large flaring spout upon a gourd-shape body. In many instances this form of spout is provided with two handles, giving the jar a classical appearance not found in other West Indian water vessels. Two specimens are shown in plate viII, $e, f$. Specimen $e$ has the usual conventionalized heads which served as handles, and incised lines forming a decorative band between them. Height of specimen, 4 inches ( $0.2 \mathrm{~cm}$.). Figure $f$ originally had two handles, broad and flat, joining the body of the vessel and curving over, forming a junction with the neck, and continuing around the latter in a raised band. This type

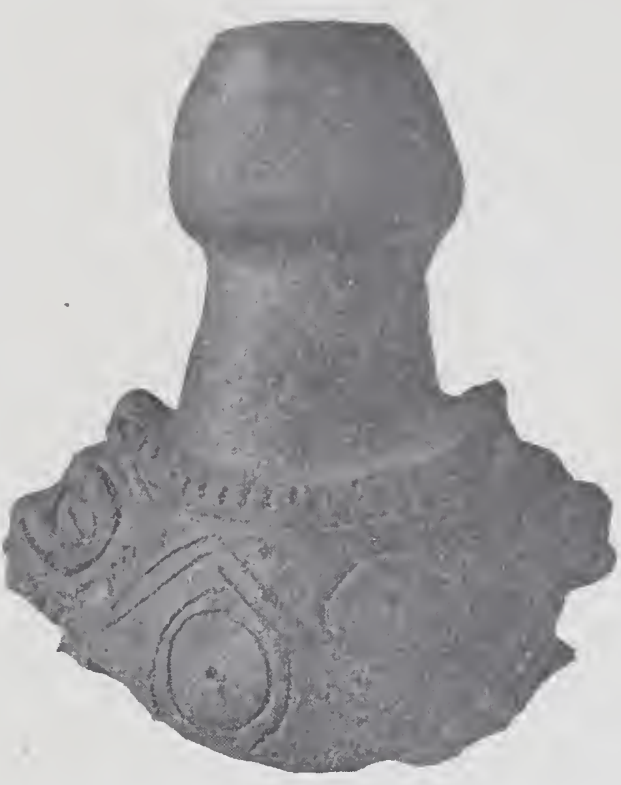

FIG. 26.-Neck of water vessel from Salado caves. of handle appears to be new in Antillean pottery. Height of specimen, 4 inches (I0.2 cm.).

Two other entire vessels, besides the one shown in plate VI, $a$, were recovered from the Salado caves. One of these (pl. v, a) is the simplest form of the double-gourd type of water-jar and lacks even the most elementary form of ornamentation. The body of the vessel is globular, narrowing into a neck superimposed by a conical spout. This specimen is of dark-brown clay of a poor quality, and is 8 inches $(20.3 \mathrm{~cm}$.) in height. The other vessel (pl. vi, $b$ ) was recovered, by diving, from the lake in one of the caves. When first seen in the water, the vessel was entire, possibly having slipped out of an Indian's hand while being filled with water. On coming to the surface with the vessel, the diver accidently struck it against a projecting rock, breaking it, but the missing part was 
recovered after further diving. The jar was in an extremely poor condition from long soaking, and showed a tendency to crumble at the slightest touch. Despite every precaution in packing, the specimen arrived broken into about fifty pieces. It was, however, finally mended and now ranks as an important accession to the Santo Domingo collections. This ressel, which is of yellow clay, has a flask-shaped body; the neck is ornamented with two small lugs. Height of specimen, 9 inches $(22.9 \mathrm{~cm}$.).

The author collected a few fragments of vessels of the mammæ type described by Dr Fewkes, ${ }^{1}$ but was not fortunate enough to be able to procure an entire specimen of this shape. Plate vII, $d$, shows enough of one of these vessels, however, to admit of the reconstruction of the original jar. An attempt to model and incise a human face has been made on the neck of the vessel, and two conventionalized heads are added to serve as handles or lugs. The spout has the conical enlargement noted in a few other specimens. In the object illustrated, these extensions are not tipped with a nipple, as in the specimen figured by Dr Fewkes; otherwise the jar is similar. Height of specimen, 7 inches (I $7.8 \mathrm{~cm}$.).

The writer does not attribute any phallic significance to the fact that the lateral extensions of such vessels resemble mammæ and that the shape of the necks may suggest a phallus, as noted by Dr Fewkes. This author does not definitely state that this similarity has a phallic meaning, merely saying that it suggests phallicism. The resemblance referred to was justified at the time Dr Fewkes wrote, inasmuch as other specimens with this form of neck had not been described. As the present writer, however, was so fortunate as to find a number of fragmentary vessels with necks bearing more or less resemblance to phalli, regardless of whether the vessel was of a "mammæ type" or a "gourd type," he does not consider that the form of the neck has any bearing on the fact that the "mammæ type" of vessel has two breast-like terminations.

Practically no pottery, other than water vessels, was found in the caves of Salado. A few fragments of heavy clay griddles, such

' J. Walter Fewkes, "The Aborigines of Porto Rico," 25th Annual Report of the Bureau of American Ethnology, I907, p. I86. 

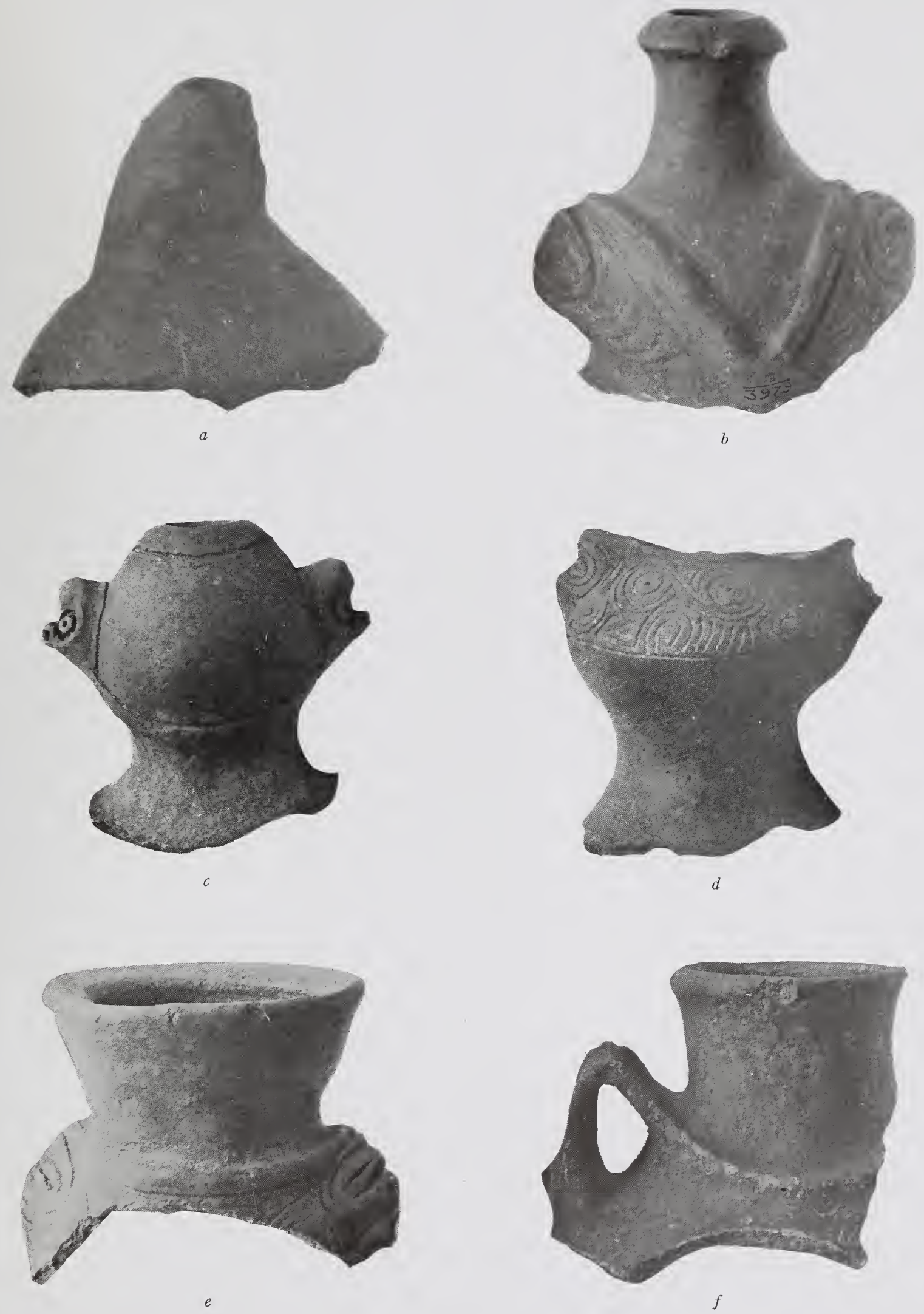

NECKS OF VARIOUS TYPES OF WATER VESSELS FROM THE SALADO CAVES 

as the author has described in a paper on the archeology of Jamaica, ${ }^{1}$ were found, and the sherds of a few cooking pots and eating bowls. One of the latter is shown in plate VII, e. This shallow bowl, of reddish-brown clay, is of graceful outline, with a broad, incurving rim, and resembles somewhat the boat-shaped vessels from Jamaica. The ends of the vessel extent slightly upward and each terminates in a conventionalized head. The rim is ornamented with incised lines, terminating in pits, in typical Antillean style. The lower part of the bowl is plain. Width of bowl between handles, $71 / 2$ inches ( $19 \mathrm{~cm}$.).

In the Salado caves were found also a number of pottery objects resembling stamps. These ma y be classed in two varieties: (I) those

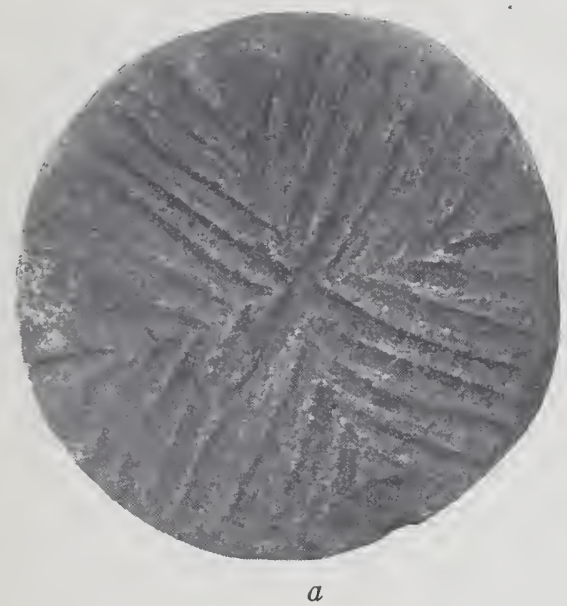

FIG. 27.-Clay disks with incised design.

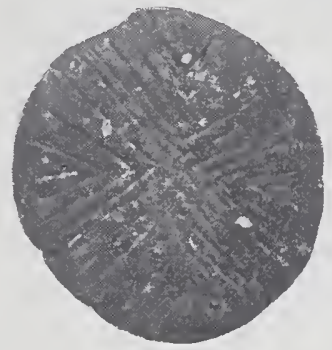

$b$

that are circular or oval and have an incised design on both sides (fig. 27, a, b), and (2) those surmounted by a raised figure on one side and with an incised pattern on the reverse (pl. Ix and fig. 28). The circular specimens illustrated in figure 27 have the same incised design on each face. A number of objects of this type was found, including some oval in shape. The diameter of $a$ is 3 inches $(7.6$ $\mathrm{cm}$.), and of $b 2$ inches (5.I cm.). It will be noted that the speci. mens shown in plate Ix and figure 28 are surmounted by small animal figures with outspread legs, luted to the surface of the stamp. In the body of the animal, which is raised and hollow, the potter

1 Theodoor de Booy, "Certain Kitchen-middens in Jamaica," American Anthro. pologist, N.S., vol. xv, no. 3, July-Sept., I9I3, p. 434. 
put certain small objects, such as seeds or stones, so that they served both as stamps and as rattles. The method of manufacture of these objects can be clearly seen in figure $28, a$, as evidently the semiglobular clay covering of the stamp-rattle did not adhere to the body in the firing or else it afterward became detached. This specimen also enables one to observe that the potter first made the stamp, and then fashioned a shallow cup-like depression in the body of the animal surmounting it. The cup was then covered with a semiglobular disk of clay, some small seeds or stones being first placed in the cavity. The covering overlapped the edges of the lower part, and then was smoothed down until united with the stamp proper. Of the stamps illustrated, those shown in plate IX, $a$, and figure 28

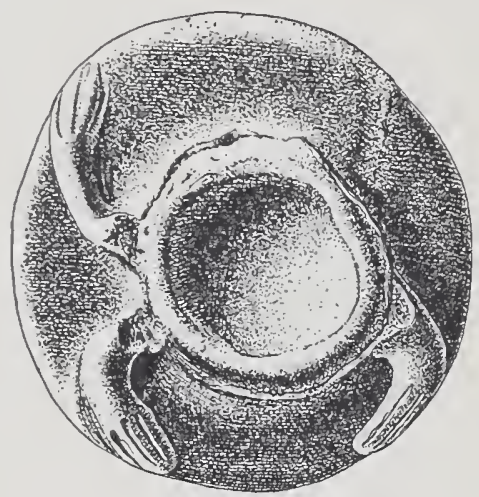

$a$, Obverse.

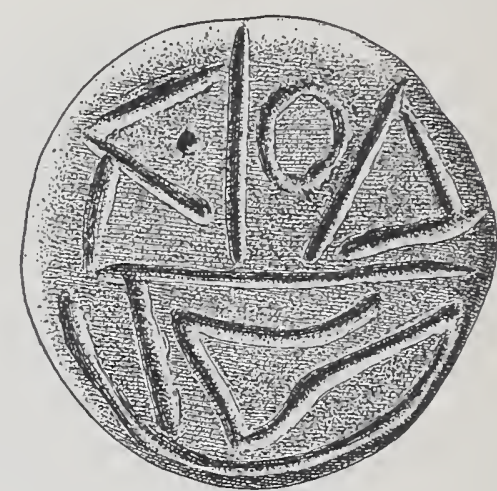

$b$, Reverse.

FIG. 28.-Clay stamp from the Salado caves.

are circular, and those in plate $\mathrm{Ix}, b, c, d$, rectangular. The reverse sides of the five stamps are exhibited in $a^{\prime}, b^{\prime}, c^{\prime}, d^{\prime}$, and figure $28, b$. As will be seen, $a^{\prime}, c^{\prime}$, and $d^{\prime}$ have the same type of incised design as the flat disks shown in figure 27. Design $b^{\prime}$ is quite different, and to some extent resembles the swastika. Figure $28, b$, also differs from any of the others in that it probably represents a highly conventionalized bird. Diameter of $a$ (pl. Ix), $21 / 8$ inches $(5.4 \mathrm{~cm}$.); width of $b, 21 / 4$ inches $(5.7 \mathrm{~cm}$.); width of $c, 21 / 4$ inches $(5.7 \mathrm{~cm}$.); width of $d, 23 / 4$ inches $\left(6.9 \mathrm{~cm}\right.$.); diameter of $a$ (fig. 28), $2 \frac{1}{8}$ inches $(5.4 \mathrm{~cm}$.$) .$

One of the objects described above is figured in Dr Fewkes' report on the Aborigines of Porto Rico (plate Lxxxvi, $b, b^{\prime}$ ). The reverse side "suggests that it had a handle (now broken) attached to the middle," which handle probably was the body of an animal 


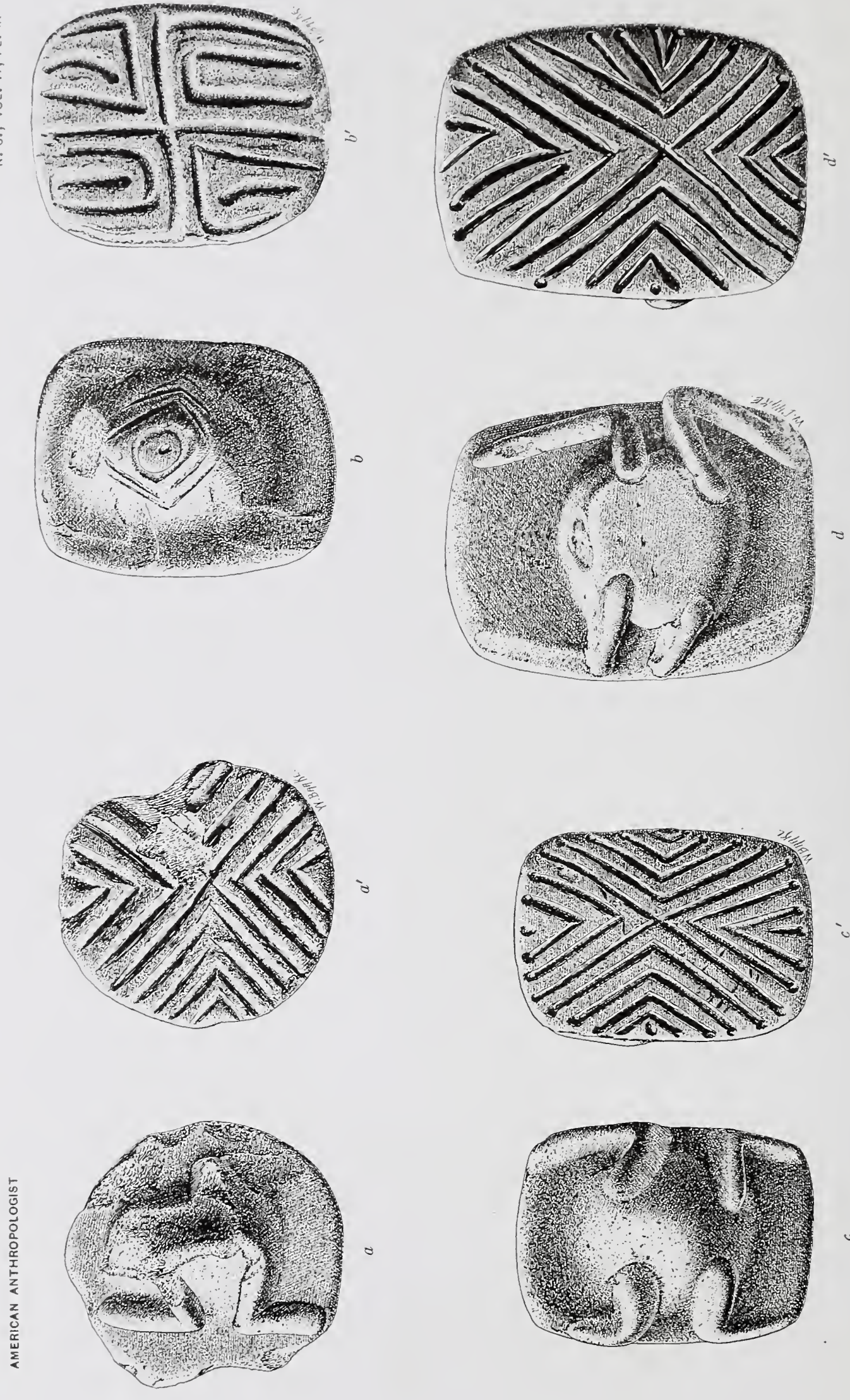
figure, of which the legs, shown by incised lines, can still be seen. One may also observe two incised lines, resembling antennæ, which suggest that the animal intended to be represented by the potter is an insect of the Coleoptera family.

This account does not include a description of many water vessels of the same type, but with slight variations as to design and ornamentation, from the Salado caves. Extended description of these would be out of place in this report, but will be considered in a later publication.

The Heye Museum NEW YORK CITY 



